\title{
Vertical distribution and storage of soil organic and inorganic carbon in a typical inland river basin, Northwest China
}

\author{
YANG Fan ${ }^{1,2}$, HUANG Laiming ${ }^{2,3}$, YANG Renmin ${ }^{1}$, YANG Fei ${ }^{1}$, LI Decheng ${ }^{1}$, ZHAO \\ Yuguo $^{1,2}$, YANG Jinling ${ }^{1}$, LIU Feng ${ }^{1}$, ZHANG Ganlin ${ }^{1,2^{*}}$ \\ ${ }^{1}$ State Key Laboratory of Soil and Sustainable Agriculture, Institute of Soil Science, Chinese Academy of Sciences, Nanjing \\ 210008, China; \\ ${ }^{2}$ University of Chinese Academy of Sciences, Beijing 100049, China; \\ ${ }^{3}$ Key Laboratory of Ecosystem Network Observation and Modeling, Institute of Geographic Sciences and Natural Resources \\ Research, Chinese Academy of Sciences, Beijing 100101, China
}

\begin{abstract}
Knowledge of soil carbon (C) distribution and its relationship with the environment can improve our understanding of its biogeochemical cycling and help to establish sound regional models of $\mathrm{C}$ cycling. However, such knowledge is limited in environments with complex landscape configurations. In this study, we investigated the vertical distribution and storage of soil organic carbon (SOC) and soil inorganic carbon (SIC) in the 10 representative landscapes (alpine meadow, subalpine shrub and meadow, mountain grassland, mountain forest, typical steppe, desert steppe, Hexi Corridor oases cropland, Ruoshui River delta desert, Alxa Gobi desert, and sandy desert) with contrasting bioclimatic regimes in the Heihe River Basin, Northwest China. We also measured the ${ }^{87} \mathrm{Sr} /{ }^{86} \mathrm{Sr}$ ratio in soil carbonate to understand the sources of SIC because the ratio can be used as a proxy in calculating the contribution of pedogenic inorganic carbon (PIC) to total SIC. Our results showed that SOC contents generally decreased with increasing soil depth in all landscapes, while SIC contents exhibited more complicated variations along soil profiles in relation to pedogenic processes and parent materials at the various landscapes. There were significant differences of $\mathrm{C}$ stocks in the top meter among different landscapes, with SOC storage ranging from $0.82 \mathrm{~kg} \mathrm{C} / \mathrm{m}^{2}$ in sandy desert to $50.48 \mathrm{~kg} \mathrm{C} / \mathrm{m}^{2}$ in mountain forest and SIC storage ranging from $0.19 \mathrm{~kg} \mathrm{C} / \mathrm{m}^{2}$ in alpine meadow to $21.91 \mathrm{~kg} \mathrm{C} / \mathrm{m}^{2}$ in desert steppe. SIC contributed more than $75 \%$ of total C pool when SOC storage was lower than $10 \mathrm{~kg} \mathrm{C} / \mathrm{m}^{2}$, and the proportion of PIC to SIC was greater than $70 \%$ as calculated from Sr isotopic ratio, suggesting the critical role of PIC in the C budget of this region. The considerable variations of SOC and SIC in different landscapes were attributed to different pedogenic environments resulted from contrasting climatic regimes, parent materials and vegetation types. This study provides an evidence for a general trade-off pattern between SOC and SIC, showing the compensatory effects of environmental conditions (especially climate) on SOC and SIC formation in these landscapes. This is largely attributed to the fact that the overall decrease in temperature and increase in precipitation from arid deserts to alpine mountains simultaneously facilitate the accumulation of SOC and depletion of SIC.
\end{abstract}

Keywords: Heihe River Basin; arid ecosystem; soil landscape; pedogenesis; pedogenic carbonate; $\mathrm{SOC}$; $\mathrm{CaCO}_{3}$

Citation: YANG Fan, HUANG Laiming, YANG Renmin, YANG Fei, LI Decheng, ZHAO Yuguo, YANG Jinling, LIU Feng, ZHANG Ganlin. 2018. Vertical distribution and storage of soil organic and inorganic carbon in a typical inland river basin, Northwest China. Journal of Arid Land, 10(2): 183-201. https://doi.org/10.1007/s40333-018-0051-9

\footnotetext{
*Corresponding author: ZHANG Ganlin (E-mail: glzhang@issas.ac.cn)

Received 2017-08-20; revised 2017-11-06; accepted 2017-12-16

(C) Xinjiang Institute of Ecology and Geography, Chinese Academy of Sciences, Science Press and Springer-Verlag GmbH Germany, part of Springer Nature 2018
} 


\section{Introduction}

Soil represents the largest carbon (C) pool (2500 Pg) in the terrestrial ecosystem, storing approximately twice the quantity of $\mathrm{C}$ in the atmosphere $(760 \mathrm{Pg})$ and vegetation $(560 \mathrm{Pg})$ (Schlesinger, 1997; Eswaran et al., 2000; Lal, 2004a). Thus, an increase in C storage capacity of soils would be an ideal option for reducing atmospheric $\mathrm{CO}_{2}$ (Lal, 2004b; Trumbore and Czimczik, 2008). Soil C pool consists of soil organic carbon (SOC) and soil inorganic carbon (SIC). The abundance of SOC is often controlled by the balance of natural and anthropogenic $\mathrm{C}$ inputs (e.g., plant residues and manuring) and outputs through soil organic matter (SOM) decomposition (Wynn et al., 2006). The estimated global SOC storage in the top meter ranges from 1200 to $1600 \mathrm{Pg}$ (Eswaran et al., 1995; Batjes, 1996). SIC occurs primarily as carbonate minerals (Batjes, 1996), such as calcite $\left(\mathrm{CaCO}_{3}\right)$ and dolomite $\left(\mathrm{CaMg}\left(\mathrm{CO}_{3}\right)_{2}\right)$. Theoretically, the SIC pool can be divided into lithogenic inorganic C (LIC) and pedogenic inorganic C (PIC). The former is inherited from the soil parent material with no chemical change, and the latter is formed during the precipitation of $\mathrm{Ca}^{2+}$ and/or $\mathrm{Mg}^{2+}$ and bicarbonate (West et al., 1988; Lal, 2004c; Liu et al., 2014). Consequently, PIC formation might sequester atmospheric $\mathrm{CO}_{2}$ in soils, depending on the sources of $\mathrm{Ca}^{2+}$ or $\mathrm{Mg}^{2+}$ (Monger and Martinez-Rios, 2000). For example, if the $\mathrm{Ca}^{2+}$ or $\mathrm{Mg}^{2+}$ originates from the dissolution of carbonate minerals during pedogenesis, thus there is no net change in C storage (Monger et al., 2015; Schlesinger, 2017); however, if the $\mathrm{Ca}^{2+}$ or $^{\mathrm{Mg}^{2+}}$ results from the weathering of $\mathrm{Ca}$ or $\mathrm{Mg}$-bearing silicate minerals, then there will be a net increase in the PIC pool (Monger and Martinez-Rios, 2000; Chang et al., 2012; Monger et al., 2015). In addition, exogenous sources of $\mathrm{Ca}^{2+}$ and/or $\mathrm{Mg}^{2+}$ imported from dust, rain and irrigation can also result in a SIC sink (Chang et al., 2012; Bughio et al., 2016). The estimated global SIC storage in the top meter varies from 700 to $1700 \mathrm{Pg}$ (Eswaran et al., 1995, 2000; Batjes, 1996). The large variations in the estimation of global SOC and SIC stocks by different researchers are partly attributed to the uncertainties in calculating $\mathrm{C}$ storage in regions with contrasting landscapes and bioclimatic conditions. Thus, a better knowledge of SOC and SIC distribution and their influencing factors in regions with different landscapes and bioclimatic conditions are not only meaningful in understanding their regional heterogeneity, but also important for accurately estimating the terrestrial C pool.

Covering $47.2 \%$ of the terrestrial area, drylands play an important role in the global $\mathrm{C}$ cycle (Lal, 2004c; Li et al., 2015). Dryland soils contain 241 Pg of SOC (Eswaran et al., 2000), and store at least as much SIC as SOC pool (Eswaran et al., 2000; Lal, 2004c). Previous studies suggested that dryland ecosystems have a strong $\mathrm{C}$ sequestration potential (Lal, 2004c; Li and Shao, 2014; Li et al., 2015). Yet little information is available on the distribution and storage of SOC and SIC in the dryland regions, due to their highly heterogeneous environmental conditions. The Heihe River Basin (HRB) is the second largest inland river basin in the arid and semi-arid regions of Northwest China (Kang et al., 2007; Cheng et al., 2014). Alternating mountains, oases, and deserts are typical landscapes in the HRB, showing evident vertical zonal characteristics of climate, vegetation and soils (Kang et al., 2007; Yang et al., 2017). So HRB is very suitable for studying the $\mathrm{C}$ distribution patterns across different landscapes from the alpine to the Gobi ecosystems. Yang et al. (2017) found that SOM accumulation, carbonate leaching and calcification are the predominant pedogenic responses to soil forming processes in the HRB. As a result, the gained, lost and existing SOC and SIC pools as well as the distributions in soil profiles across different landscapes have important ecological implications in the inland river basins.

There have been many studies in the past several decades investigating the storage and distribution of SOC at different spatial scales (Batjes, 1996; Schlesinger, 1997; Eswaran et al., 2000; Jobbágy and Jackson, 2000; Wu et al., 2003a; Lal, 2004a; Wang et al., 2004; Baumann et al., 2009; Yang et al., 2016) and their evolution under the influences of natural and anthropogenic perturbations in Northwest China (Wang et al., 2004; Wang et al., 2005; Kang et al., 2007; Li and Shao, 2014; Lü et al., 2014; Su et al., 2015; Chen et al., 2016; Yang et al., 2016). However, little attention has been paid to SIC, in spite of its relative abundance in the arid and semi-arid regions. Several studies have demonstrated that the SIC pool in the northern China is one to nine times 
higher than the SOC stock (Mi et al., 2008; Wu et al., 2009; Wang et al., 2010; Wang et al., 2015; Zhang et al., 2015). Often, environments with adequate precipitation favoring SOC accumulation have little SIC, while SIC-rich soils occur in the arid and semi-arid regions with lower biomass production and little SOC. This suggests that there may be an offset effect between SOC and SIC. Thus, studies focusing only on SOC dynamics without consideration of SIC may underestimate the $\mathrm{C}$ sequestration potential of the terrestrial ecosystem, especially in the arid and semi-arid regions where SIC stock is often much higher than SOC stock (Eswaran et al., 2000; Zhang et al., 2015).

The objectives of the present study were to investigate the vertical distribution and storage of SOC and SIC across different landscapes in the HRB and to identify the relative roles of climatic, edaphic and biotic factors in determining SOC and SIC storage and their vertical distribution patterns. Results of this study are essential to improve our understanding of regional $\mathrm{C}$ cycle in relation to the high spatial heterogeneity of climatic conditions, vegetation types and soil properties in the arid inland river basins of Northwest China.

\section{Materials and methods}

\subsection{Study area}

The Heihe River Basin (HRB) is located in the arid and semi-arid regions of Northwest China $\left(37^{\circ} 72^{\prime}-42^{\circ} 68^{\prime} \mathrm{N}, 97^{\circ} 04^{\prime}-102^{\circ} 00^{\prime} \mathrm{E}\right.$ ), covering an area of approximately $1.28 \times 10^{5} \mathrm{~km}^{2}$ (Cheng et al., 2014). Geographically, the Heihe River can be divided into the upper, middle and lower reaches by the Yingluoxia and Zhengyixia hydrological stations, respectively (Fig. 1). The Qilian Mountains attach to the upstream areas, the middle Hexi Corridor belongs to the midstream regions and the northern Alxa High-Plain belongs to the downstream areas. The Qilian Mountains at the upstream areas have elevations ranging from 2000 to $5500 \mathrm{~m}$. The mean annual precipitation (MAP) increases from 100 to $500 \mathrm{~mm}$, while the annual mean temperature (AMT) decreases from $6^{\circ} \mathrm{C}$ to $-8^{\circ} \mathrm{C}$ with increasing elevation. The upstream areas can be divided into glacier, snow zone, permafrost zone, mountain forest and grassland zone, and steppe zone according to the elevation and local topography (Kang et al., 2007; Qin et al., 2013; Yin et al., 2015). The middle Hexi Corridor with alluvial fans and floodplains is located between the Qilian Mountains and the Beishan Mountains. The precipitation is scarce in this region, and the limited water resources are collectively utilized in the artificial oases by the highly developed irrigation system (Wang et al., 2007; Cheng et al., 2014), where irrigated agriculture is very well developed. The lower reaches of the Heihe River flow across the Alxa High-Plain with a mean elevation of $1000 \mathrm{~m}$. This region is extremely arid with MAP less than $50 \mathrm{~mm}$ and annual potential evaporation greater than $3500 \mathrm{~mm}$ (Yin et al., 2015), where desert and Gobi prevail.

\subsection{Field investigations}

A total of 10 representative landscapes were selected in the HRB (Table 1): alpine meadow (AM), subalpine shrub and meadow (SSM), mountain grassland (MG), mountain forest (MF), typical steppe (TS), desert steppe (DS), Hexi Corridor oases cropland (HCO), Ruoshui River delta desert (RDD), Alxa Gobi desert (AGD), and sandy desert (SD). Field soil survey and sampling were conducted during the summer months (July to August) of 2012 and 2013. Three sampling sites were set in each landscape, with a total of 30 sites in the whole study area (Fig. 1). Geographic coordinates and elevations of each sampling site were recorded using a GPS unit (Juno SB, Trimble, USA), and the plant species were also recorded. In each sampling site, a soil pit was hand dug to a depth of $120 \mathrm{~cm}$ (or bedrock). Soil samples were collected according to genetic horizons (Appendix, Table S1). The samples were air-dried and then sieved through a 2-mm nylon mesh. A subsample of the air-dried sample was ground using a pestle and mortar to pass through a $0.25-\mathrm{mm}$ nylon sieve before laboratory analyses of $\mathrm{SOC}$ and $\mathrm{CaCO}_{3}$ contents. In addition, undisturbed soil samples from each genetic horizon were collected in triplicate using a cutting ring $(5 \mathrm{~cm}$ in diameter and $5 \mathrm{~cm}$ in height) for bulk density (BD) determination. The volume percentage of coarse fragments (diameter $>2 \mathrm{~mm}$ ) was determined by visual estimation in the field. 


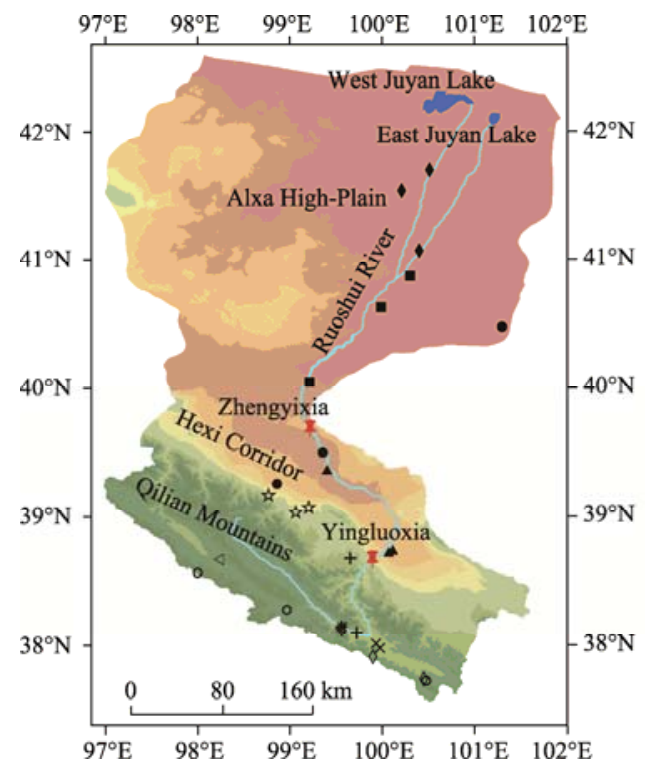

Legend

₹ Hydrological station

- Lake

- River

Sampling site

- Alpine meadow

- Subalpine shrub and meadow

$\triangleleft$ Mountain grassland

$\times$ Mountain forest

+ Typical steppe

\& Desert steppe

- Hexi Corridor oases cropland

- Ruoshui River delta desert

- Alxa Gobi desert

- Sandy desert

Elevation (m)

$\square$ 800-1200

$\square 1200-1400$

$\square$ 1400-1600

$\square$ 1600-1800

$\square$ 1800-2000

$\square$ 2000-2700

$\square$ 2700-3400

- 3400-4100

- 4100-4600

Fig. 1 Overview of the Heihe River Basin (HRB) and locations of the sampling sites

Table 1 Characteristics of the 10 representative landscapes in the Heihe River Basin (HRB)

\begin{tabular}{|c|c|c|c|c|c|c|c|}
\hline Landscape & $\begin{array}{l}\text { Altitude } \\
\qquad(\mathrm{m})\end{array}$ & $\begin{array}{l}\text { MAP } \\
(\mathrm{mm})\end{array}$ & $\begin{array}{l}\mathrm{AMT} \\
\left({ }^{\circ} \mathrm{C}\right)\end{array}$ & Dominant species & $\begin{array}{c}\text { Canopy } \\
\text { cover } \\
(\%)\end{array}$ & $\begin{array}{l}\text { Parent } \\
\text { material }\end{array}$ & Soil type \\
\hline AM & $\begin{array}{c}3899 \\
( \pm 275)\end{array}$ & $\begin{array}{c}324 \\
( \pm 21)\end{array}$ & $\begin{array}{l}-4.5 \\
( \pm 2.0)\end{array}$ & Kobresia humilis, Carex tristachya & $\begin{array}{c}75 \\
( \pm 9)\end{array}$ & EOD, TIL & Histic Cryosols \\
\hline SSM & $\begin{array}{r}3508 \\
( \pm 191)\end{array}$ & $\begin{array}{c}332 \\
( \pm 18)\end{array}$ & $\begin{array}{l}-2.5 \\
( \pm 1.2)\end{array}$ & $\begin{array}{l}\text { Salix cupularis, Potentilla fruticosa, } \\
\text { Caragana jubata, Kobresia humilis }\end{array}$ & $\begin{array}{c}57 \\
( \pm 13)\end{array}$ & LOE, SAL & $\begin{array}{c}\text { Cambic } \\
\text { Phaeozems }\end{array}$ \\
\hline MG & $\begin{array}{c}3212 \\
( \pm 174)\end{array}$ & $\begin{array}{c}376 \\
( \pm 28)\end{array}$ & $\begin{array}{c}-0.4 \\
( \pm 0.9)\end{array}$ & $\begin{array}{c}\text { Poa annua, Elymus dahuricus, Kobresia } \\
\text { humilis, Polygonum viviparum }\end{array}$ & $\begin{array}{l}85 \\
( \pm 6)\end{array}$ & LOE, ALL & $\begin{array}{c}\text { Calcic } \\
\text { Kastanozems }\end{array}$ \\
\hline $\mathrm{MF}$ & $\begin{array}{l}3016 \\
( \pm 35)\end{array}$ & $\begin{array}{c}308 \\
( \pm 18)\end{array}$ & $\begin{array}{c}0.4 \\
( \pm 0.3)\end{array}$ & Picea crassifolia, Kobresia humili & $\begin{array}{c}90 \\
( \pm 5)\end{array}$ & LOE, SAL & $\begin{array}{c}\text { Chernic } \\
\text { Phaeozems }\end{array}$ \\
\hline TS & $\begin{array}{c}2848 \\
( \pm 118)\end{array}$ & $\begin{array}{c}272 \\
( \pm 28)\end{array}$ & $\begin{array}{c}0.9 \\
( \pm 0.7)\end{array}$ & $\begin{array}{c}\text { Achnatherum splendens, Stipa krylovii, Poa } \\
\text { annua }\end{array}$ & $\begin{array}{c}44 \\
( \pm 6)\end{array}$ & $\mathrm{LOE}$ & Cambic Calcisols \\
\hline DS & $\begin{array}{l}2039 \\
( \pm 150)\end{array}$ & $\begin{array}{c}144 \\
( \pm 12)\end{array}$ & $\begin{array}{c}4.9 \\
( \pm 0.7)\end{array}$ & $\begin{array}{c}\text { Sympegma regelii, Pennisetum } \\
\text { centrasiaticum, Achnatherum splendens }\end{array}$ & $\begin{array}{c}13 \\
( \pm 4)\end{array}$ & LOE & Cambic Calcisols \\
\hline $\mathrm{HCO}$ & $\begin{array}{c}1488 \\
( \pm 137)\end{array}$ & $\begin{array}{c}120 \\
( \pm 21)\end{array}$ & $\begin{array}{c}7.7 \\
( \pm 0.6)\end{array}$ & Zea mays, Triticum aestivum & $\begin{array}{c}90 \\
( \pm 5)\end{array}$ & HTM & Irragric Anthrosols \\
\hline RDD & $\begin{array}{l}1125 \\
( \pm 74)\end{array}$ & $\begin{array}{c}52 \\
( \pm 18)\end{array}$ & $\begin{array}{c}8.7 \\
( \pm 0.1)\end{array}$ & & - & ALL & Skeletic Fluvisols \\
\hline AGD & $\begin{array}{c}997 \\
( \pm 34)\end{array}$ & $\begin{array}{c}32 \\
( \pm 7)\end{array}$ & $\begin{array}{c}8.7 \\
( \pm 0.1)\end{array}$ & & - & EOD, ALL & Fluvic Cambisols \\
\hline $\mathrm{SD}$ & $\begin{array}{c}1327 \\
( \pm 266)\end{array}$ & $\begin{array}{c}80 \\
( \pm 30) \\
\end{array}$ & $\begin{array}{c}8.2 \\
( \pm 0.9)\end{array}$ & & - & EOS & Calcaric Arenosols \\
\hline
\end{tabular}

Note: AM, alpine meadow; SSM, subalpine shrub and meadow; MG, mountain grassland; MF, mountain forest; TS, typical steppe; DS, desert steppe; HCO, Hexi Corridor oases cropland; RDD, Ruoshui River delta desert; AGD, Alxa Gobi desert; SD, sandy desert. It should be noted that RDD, AGD and SD are barren lands without vegetation. -, no data; MAP, mean annual precipitation; AMT, annual mean temperature. Soil types were classified according to the World Reference Base for Soil Resources (IUSS Working Group, 2014). Parent material terminology follows the methods of Schoeneberger et al. (2012). EOD, aeolian deposit; TIL, till; LOE, loess; ALL, alluvium; SAL, slope alluvium; HTM, human-transported materials (Siltigation in Chinese Soil Taxonomy); EOS, aeolian sands. The values in brackets are the standard errors.

\subsection{Soil laboratory analysis}

Soil $\mathrm{pH}$ was measured using a digital $\mathrm{pH}$ meter in a 1:2.5 soil:water solution. Soil BD was measured by drying the undisturbed soil samples at $105^{\circ} \mathrm{C}$ to a constant weight. Soil particle size fractions were analyzed by a laser diffraction particle size analyzer (LS230, Beckman Coulter, USA). Prior to the analysis, about $0.2 \mathrm{~g}$ soil samples (diameter $<2 \mathrm{~mm}$ ) were prepared by adding $30 \% \mathrm{H}_{2} \mathrm{O}_{2}$ and $10 \% \mathrm{HCl}$ to remove organic matter and carbonate, $0.5 \mathrm{~mol} / \mathrm{L} \mathrm{Na}_{2} \mathrm{C}_{2} \mathrm{O}_{4}$ and 0.5 $\mathrm{mol} / \mathrm{L}\left(1 / 6 \mathrm{NaPO}_{3}\right)_{6}$ were respectively used as the dispersant for neutral and alkaline soils, and the sample solution was ultrasonicated for $10 \mathrm{~min}$ before transferred to the LS230 analyzer. The $\mathrm{CaCO}_{3}$ equivalent was analyzed volumetrically, i.e., by measuring the volume of $\mathrm{CO}_{2}$ that was 
generated by the action of $10 \% \mathrm{HCl}$ on soil carbonate. SOC content was determined by the $\mathrm{K}_{2} \mathrm{Cr}_{2} \mathrm{O}_{7}-\mathrm{H}_{2} \mathrm{SO}_{4}$ wet oxidation method of Walkey-Black (Nelson and Sommers, 1982).

Since $\mathrm{Sr}$ and $\mathrm{Ca}$ have similar geochemical behaviors, in order to identify the sources of SIC, we measured the ${ }^{87} \mathrm{Sr} /{ }^{86} \mathrm{Sr}$ ratio in soil carbonate because it can be used as a proxy for calculating the contribution of pedogenic inorganic C (PIC) to total SIC. The method of Chen et al. (1997) was adopted to dissolve carbonate in the selected loess and siltigation samples, due to that $0.5 \mathrm{~mol} / \mathrm{L}$ acetic acid solution dissolves carbonate only and does not attack other minerals. In detail, about $500 \mathrm{mg}$ of $74 \mu \mathrm{m}$ (200 mesh) sample was weighted and dipped in a Teflon container with $20 \mathrm{~mL}$ of $0.5 \mathrm{~mol} / \mathrm{L} \mathrm{HOAc}$ solution at room temperature for $8 \mathrm{~h}$. Then, the HOAc leachates were evaporated in Teflon tubes after addition of $3 \mathrm{~mol} / \mathrm{L} \mathrm{HNO}_{3}$. The $\mathrm{Sr}$ isotopic ratios were determined with a Finnigan MAT262 mass spectrometer (Bremen, Germany), installed at the Laboratory for Radiogenic Isotope Geochemistry, University of Science and Technology of China. All ${ }^{87} \mathrm{Sr} /{ }^{86} \mathrm{Sr}$ ratio values were normalized to the National Institute of Science and Technology (NIST) Strontium Carbonate Isotopic Standard (NBS987) value of $0.710288( \pm 0.000013)(2 \sigma$ standard deviation, $n=8$ ).

\subsection{Data collection and statistical analysis}

Climate data were obtained from the dataset produced by the Chinese Academy of Agricultural Sciences (http://cdc.nmic.cn/home.do), with a spatial resolution of $1000 \mathrm{~m}$. Data of MAP and AMT for each sampling site were extracted on the basis of the geographical locations.

We measured the ${ }^{87} \mathrm{Sr} /{ }^{86} \mathrm{Sr}$ ratio in soil carbonate as a proxy for calculating the percentage of PIC in total SIC (Chen et al., 1997).

$$
\begin{gathered}
\mathrm{PIC}_{i} \%=\frac{\left({ }^{87} \mathrm{Sr} /{ }^{86} \mathrm{Sr}\right)_{i}-0.7080}{0.004} \times 100 \%, \\
\mathrm{PIC}_{i}=0.12 \times \mathrm{CaCO}_{3 i} \times \mathrm{PIC}_{i} \%,
\end{gathered}
$$

where $\mathrm{PIC}_{i} \%$ is the percentage of pedogenic carbonate in total carbonate of the $i^{\text {th }}$ horizon; $\left({ }^{87} \mathrm{Sr} /{ }^{86} \mathrm{Sr}\right)_{i}$ denotes the $\mathrm{Sr}$ isotopic composition of the $i^{\text {th }}$ horizon in soil carbonate fraction of the $0.5 \mathrm{~mol} / \mathrm{L}$ HOAc dissolved component; $\mathrm{PIC}_{i}$ and $\mathrm{CaCO}_{3 i}$ are the pedogenic inorganic $\mathrm{C}$ content and $\mathrm{CaCO}_{3}$ equivalent content of the $i^{\text {th }}$ horizon $(\mathrm{g} / \mathrm{kg})$, respectively; and 0.12 is the conversion factor from $\mathrm{CaCO}_{3}$ content to inorganic $\mathrm{C}$ content.

This study analyzed the spatial distribution of soil $\mathrm{C}$ storage of the top meter. Also, standard depths with ranges of $0-30$ and $0-50 \mathrm{~cm}$ were used to facilitate comparisons with previous studies. For each sampling site, the values of SOC and SIC density $\left(\mathrm{kg} \mathrm{C} / \mathrm{m}^{2}\right)$ on a volume basis were calculated using the following equations:

$$
\begin{gathered}
\operatorname{SOCD}_{h}=\sum_{i=1}^{k} \rho_{i} \times \mathrm{SOC}_{i} \times D_{i} \times\left(1-S_{i}\right), \\
\operatorname{SICD}_{h}=\sum_{i=1}^{k} 0.12 \times \rho_{i} \times \mathrm{CaCO}_{3 i} \times D_{i} \times\left(1-S_{i}\right),
\end{gathered}
$$

where $\mathrm{SOCD}_{h}$ and $\mathrm{SICD}_{h}$ are the total amount of soil organic $\mathrm{C}$ density and soil inorganic $\mathrm{C}$ density between soil surface and soil depth $h(\mathrm{~cm})$ per unit area $\left(\mathrm{kg} \mathrm{C} / \mathrm{m}^{2}\right)$, respectively; $k$ is the number of soil genetic horizons within the depth $h ; \rho_{i}$ is the bulk density of the $i^{\text {th }}$ horizon $\left(\mathrm{g} / \mathrm{cm}^{3}\right)$; $D_{i}$ is the thickness of the $i^{\text {th }}$ horizon (m); $S_{i}$ is the volume fraction of fragments $>2 \mathrm{~mm}$ of the $i^{\text {th }}$ horizon (\%); $\mathrm{SOC}_{i}$ and $\mathrm{CaCO}_{3 i}$ are the $\mathrm{SOC}$ content and $\mathrm{CaCO}_{3}$ equivalent content of the $i^{\text {th }}$ horizon $(\mathrm{g} / \mathrm{kg})$, respectively; and 0.12 is the conversion factor from $\mathrm{CaCO}_{3}$ content to inorganic $\mathrm{C}$ content.

Multiple comparisons and analyses of variance (one-way ANOVA with Duncan's multiple range test) were used to determine the significance of differences between soil $\mathrm{C}$ storage among different landscapes and among different intervals of soil depth in each landscape. Linear regression and correlation analyses were conducted to evaluate the relationship between $\mathrm{C}$ storage and climate factors (i.e., MAP, AMT). The analyses were performed with SPSS Statistics 20.0 for Windows. 


\section{Results}

\subsection{Basic soil properties in different landscapes}

Soils developed in different landscapes in the HRB were classified (Table 1) according to the World Reference Base for Soil Resources (IUSS Working Group, 2014), covering most soil types in the arid and semi-arid regions of Northwest China. Considerable changes in soil properties were observed in different landscapes (Table 2). The generalized genetic horizon sequence of soils across the representative landscapes is presented in Figure 2.

Table 2 Basic soil properties of the 10 representative landscapes in the HRB

\begin{tabular}{|c|c|c|c|c|c|c|c|c|c|c|}
\hline Landscape & Horizon & $\begin{array}{l}\text { Thickness } \\
\text { (cm) }\end{array}$ & $\begin{array}{c}\text { Gravel } \\
(\%)\end{array}$ & $\begin{array}{l}\text { Clay } \\
(\%)\end{array}$ & $\begin{array}{l}\text { Silt } \\
(\%)\end{array}$ & $\begin{array}{l}\text { Sand } \\
(\%)\end{array}$ & $\mathrm{pH}$ & $\begin{array}{c}\mathrm{BD} \\
\left(\mathrm{g} / \mathrm{cm}^{3}\right)\end{array}$ & $\begin{array}{l}\mathrm{SOM} \\
(\mathrm{g} / \mathrm{kg})\end{array}$ & $\begin{array}{c}\mathrm{CaCO}_{3} \\
(\mathrm{~g} / \mathrm{kg})\end{array}$ \\
\hline \multirow[t]{4}{*}{$\mathrm{AM}$} & $\mathrm{O}$ & $12-20$ & $8-10$ & $9-12$ & $55-63$ & $25-36$ & $6.8-7.3$ & 0.88 & $80.5-82.9$ & $1-2$ \\
\hline & $\mathrm{A}$ & $10-12$ & $15-40$ & $7-13$ & $46-64$ & $23-47$ & $6.6-7.0$ & $0.97-1.11$ & $36.3-67.0$ & $1-2$ \\
\hline & B & $20-27$ & $10-30$ & $7-8$ & $34-55$ & $38-59$ & $6.4-7.6$ & $1.22-1.33$ & $30.0-39.3$ & $1-2$ \\
\hline & $2 \mathrm{C}$ & $57-76$ & $80-85$ & $6-11$ & $26-55$ & $34-68$ & $6.3-7.8$ & $1.15-1.42$ & $7.1-51.1$ & $1-24$ \\
\hline \multirow[t]{3}{*}{ SSM } & A & $14-20$ & $3-8$ & $10-15$ & $48-70$ & $16-42$ & $6.0-8.2$ & $0.72-1.03$ & $37.8-127.3$ & $1-16$ \\
\hline & B & $21-36$ & $5-8$ & $11-15$ & $51-71$ & $14-38$ & $6.2-8.2$ & $0.84-1.17$ & $35.9-85.3$ & $1-30$ \\
\hline & $2 \mathrm{C}$ & $26-65$ & $55-85$ & $6-14$ & $37-54$ & $34-57$ & $6.9-8.6$ & $1.32-1.44$ & $4.8-10.9$ & $1-17$ \\
\hline \multirow[t]{4}{*}{ MG } & A & $14-17$ & 0 & $13-14$ & $53-72$ & $14-34$ & $7.5-8.5$ & $0.87-1.16$ & $56.7-86.3$ & $7-10$ \\
\hline & $\mathrm{AB}$ & $17-28$ & 0 & $13-15$ & $59-71$ & $16-27$ & $7.4-8.2$ & $1.05-1.17$ & $45.9-59.7$ & $9-61$ \\
\hline & B & $38-40$ & $0-15$ & $10-16$ & $56-71$ & $14-30$ & $8.2-9.1$ & $1.08-1.22$ & $9.5-47.1$ & 85-192 \\
\hline & $\mathrm{C}$ & $30-40$ & $0-30$ & $10-14$ & $56-64$ & $27-32$ & $8.8-9.6$ & $1.25-1.32$ & $5.3-7.3$ & $139-153$ \\
\hline \multirow[t]{5}{*}{ MF } & $\mathrm{O}$ & $6-15$ & 0 & $14-19$ & $66-73$ & $13-15$ & $6.9-7.6$ & $0.40-0.50$ & $176.5-203.6$ & $8-11$ \\
\hline & A & $11-22$ & 0 & $14-17$ & $65-72$ & $12-20$ & $7.2-7.7$ & $0.40-0.75$ & $115.5-227.0$ & $7-13$ \\
\hline & B & $32-60$ & $0-2$ & $11-19$ & $65-72$ & $13-23$ & $7.3-7.9$ & $0.57-0.72$ & $132.9-199.0$ & $6-11$ \\
\hline & $\mathrm{C}$ & $10-21$ & $0-50$ & $14-15$ & $69-70$ & $14-16$ & $7.4-7.9$ & $0.61-0.90$ & $89.5-178.4$ & $7-14$ \\
\hline & $2 \mathrm{C}$ & $13-19$ & $20-50$ & $12-13$ & $63-69$ & $18-25$ & $7.8-8.0$ & $0.88-1.23$ & $28.2-84.8$ & $8-41$ \\
\hline \multirow[t]{3}{*}{$\mathrm{TS}$} & A & $15-16$ & $2-5$ & $10-12$ & $61-76$ & $12-28$ & $7.8-8.4$ & $0.91-1.04$ & $42.1-57.5$ & $7-100$ \\
\hline & B & $66-70$ & $0-10$ & $12-14$ & $64-76$ & $11-23$ & $8.1-8.7$ & $1.07-1.45$ & $5.7-32.5$ & $28-202$ \\
\hline & $\mathrm{C}$ & $25-38$ & $0-10$ & $11-13$ & $67-74$ & $15-20$ & $8.8-8.9$ & $1.23-1.33$ & $7.7-8.1$ & 124-193 \\
\hline \multirow[t]{3}{*}{ DS } & A & $10-20$ & $0-3$ & $8-12$ & $56-72$ & $16-36$ & $8.3-8.6$ & $1.23-1.26$ & $10.0-11.7$ & $125-139$ \\
\hline & B & $81-95$ & $0-12$ & $7-13$ & $64-76$ & $15-29$ & $8.0-8.6$ & $1.20-1.32$ & $5.5-9.4$ & $124-160$ \\
\hline & $\mathrm{C}$ & $15-22$ & $0-1$ & $8-10$ & $62-73$ & $17-31$ & $8.2-8.8$ & $1.32-1.36$ & $4.7-7.4$ & $130-143$ \\
\hline \multirow[t]{3}{*}{$\mathrm{HCO}$} & A & $16-25$ & $1-2$ & $8-15$ & $44-64$ & $21-48$ & $7.9-8.7$ & $1.34-1.45$ & $12.8-23.7$ & $79-105$ \\
\hline & B & $55-73$ & $1-5$ & $8-16$ & $32-67$ & $21-60$ & $8.0-8.6$ & $1.25-1.55$ & $8.9-17.0$ & $64-147$ \\
\hline & $\mathrm{C}$ & $25-30$ & $1-5$ & $13-14$ & $50-68$ & $18-36$ & $8.1-8.4$ & $1.33-1.45$ & $5.0-11.4$ & $100-124$ \\
\hline \multirow[t]{2}{*}{ RDD } & A & $5-8$ & $10-40$ & $2-14$ & $9-29$ & $57-89$ & $7.6-8.6$ & $1.34-1.46$ & $2.4-5.6$ & $40-76$ \\
\hline & $\mathrm{C}$ & $102-115$ & $2-30$ & $1-6$ & $5-20$ & $74-94$ & $7.5-9.2$ & $1.37-1.57$ & $1.4-2.9$ & $34-56$ \\
\hline \multirow[t]{3}{*}{ AGD } & A & $6-10$ & $1-10$ & $10-12$ & $23-35$ & $53-67$ & $7.9-8.0$ & $1.51-1.67$ & $2.4-3.7$ & $41-100$ \\
\hline & B & $35-51$ & $10-50$ & $3-14$ & $13-30$ & $56-83$ & $7.9-9.2$ & $1.51-1.77$ & $1.4-2.5$ & $31-71$ \\
\hline & $2 \mathrm{C}$ & $48-75$ & $30-90$ & $1-5$ & $7-14$ & $81-92$ & $8.4-9.8$ & $1.55-1.68$ & $1.3-1.6$ & $8-40$ \\
\hline SD & $\mathrm{C}$ & 120 & $0-2$ & $1-3$ & $4-13$ & 84-95 & $8.5-9.3$ & $1.26-1.58$ & $0.8-1.2$ & $16-78$ \\
\hline
\end{tabular}

Note: BD, bulk density; SOM, soil organic matter; O, organic horizon; A, surface horizon; AB, transitional horizon; B, subsoil; C, substratum; 2C, a lithologic discontinuity with the overlying solum.

Soils were neutral to strongly alkaline $(6.0 \leq \mathrm{pH} \leq 9.2)$ and the fine soil was dominated by the silt fraction, except for desert soils in RDD, AGD and SD landscapes, which showed the largest proportion in the sand fraction (Table 2). Soil BD increased with increasing soil depth and showed large variations among different landscapes, with the lowest BD in MF $\left(0.40-1.23 \mathrm{~g} / \mathrm{cm}^{3}\right)$ and the highest in AGD (1.51-1.77 $\left.\mathrm{g} / \mathrm{cm}^{3}\right)$. In contrast, SOM decreased with increasing soil depth, and the highest and lowest SOM contents occurred on MF (28.2-227.0 g/kg) and SD (0.8-1.2 
$\mathrm{g} / \mathrm{kg}$ ), respectively. Consequently, BD generally showed a significant negative relationship with SOM content $(r=-0.91, P<0.001)$. In addition, the highest and lowest $\mathrm{CaCO}_{3}$ contents were observed in DS (124-160 g/kg) and AM (1-24 g/ kg), respectively. Our results demonstrated higher rates of SOM accumulation (i.e., Oi (mattic epipedon and litter layer in AM and MF, respectively) and $\mathrm{Ah}$ (mollic epipedon); Fig. 2) and $\mathrm{CaCO}_{3}$ leaching in the wetter and cooler sites as compared with those in the drier and hotter sites where the profile includes a calcic horizon (i.e., Bk (calcic horizon in the subsoil); Fig. 2) in the HRB.

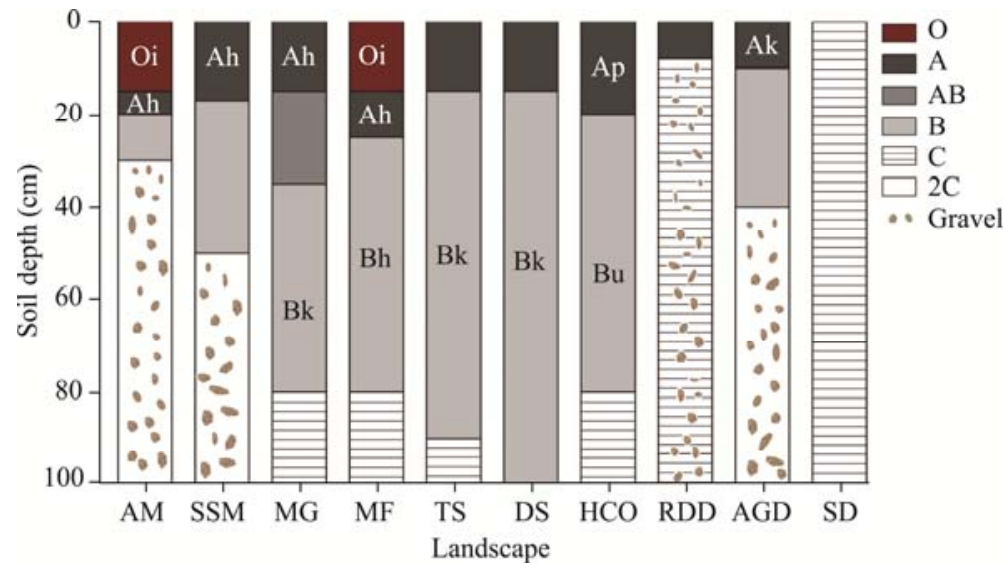

Fig. 2 Generalized genetic horizon sequence of soils in the top meter across the 10 representative landscapes. AM, alpine meadow; SSM, subalpine shrub and meadow; MG, mountain grassland; MF, mountain forest; TS, typical steppe; DS, desert steppe; HCO, Hexi Corridor oases cropland; RDD, Ruoshui River delta desert; AGD, Alxa Gobi desert; SD, sandy desert. Horizon designations follows the methods of Schoeneberger et al. (2012). O, organic horizon; A, surface horizon; AB, transitional horizon; B, subsoil; C, substratum; 2C, a lithologic discontinuity with the overlying solum. More specifically, Oi, mattic epipedon and litter layer in AM and MF, respectively; Ah, mollic epipedon; Ap, anthropic epipedon; Ak, calcic horizon in the topsoil; Bk, calcic horizon in the subsoil; $\mathrm{Bh}$, horizon of accumulation of illuvial organic matter; Bu, siltigic horizon.

\subsection{Vertical distribution patterns of soil organic and inorganic carbon in different landscapes}

The vertical distribution patterns of SOC and SIC density at $20 \mathrm{~cm}$ intervals in the top meter are presented in Figure 3. Generally, SOC density in all landscapes decreased with increasing soil depth (Fig. 3a). There were significant differences of SOC density in the top $20 \mathrm{~cm}$ layer and in the deeper layers $(P<0.05)$ in different landscapes with exceptions of RDD and SD, where SOC density was extremely low (Fig. 3a). The proportion of SOC density in the top $20 \mathrm{~cm}$ layer was the highest in AM (57\% of the SOC density in the top meter), followed by SSM (46\%), TS (38\%), AGD (38\%), and MG (35\%), suggesting accumulations of SOC in the upper layer in these landscapes. In contrast, a much lower SOC density in the top $20 \mathrm{~cm}$ layer was found in HCO (27\%), MF (25\%), DS (25\%), RDD (23\%), and SD (22\%), indicating either the importance of SOC in the deeper soil layers (i.e., HCO, MF, and DS) or low inputs of SOC in the upper layer (i.e., RDD and SD).

SIC showed different distribution patterns across different landscapes (Fig. 3b). The patterns can be categorized into three groups: (1) the relatively uniform distribution of SIC density in soil profiles found in AM, SSM, MF, RDD and SD, which exhibited no significant differences of SIC density among different layers $(P>0.05)$; (2) the enrichment of SIC in the subsoil of MG, TS, DS, and $\mathrm{HCO}$, which had significant higher SIC density in the deeper layers than the upper layer $(P<0.05)$; and (3) the accumulation of SIC in the upper layer in AGD, which showed a significant higher SIC density in the top $20 \mathrm{~cm}$ layer than the other layers $(P<0.05)$. 
(a) SOC density $\left(\mathrm{kg} \mathrm{C} / \mathrm{m}^{2}\right)$
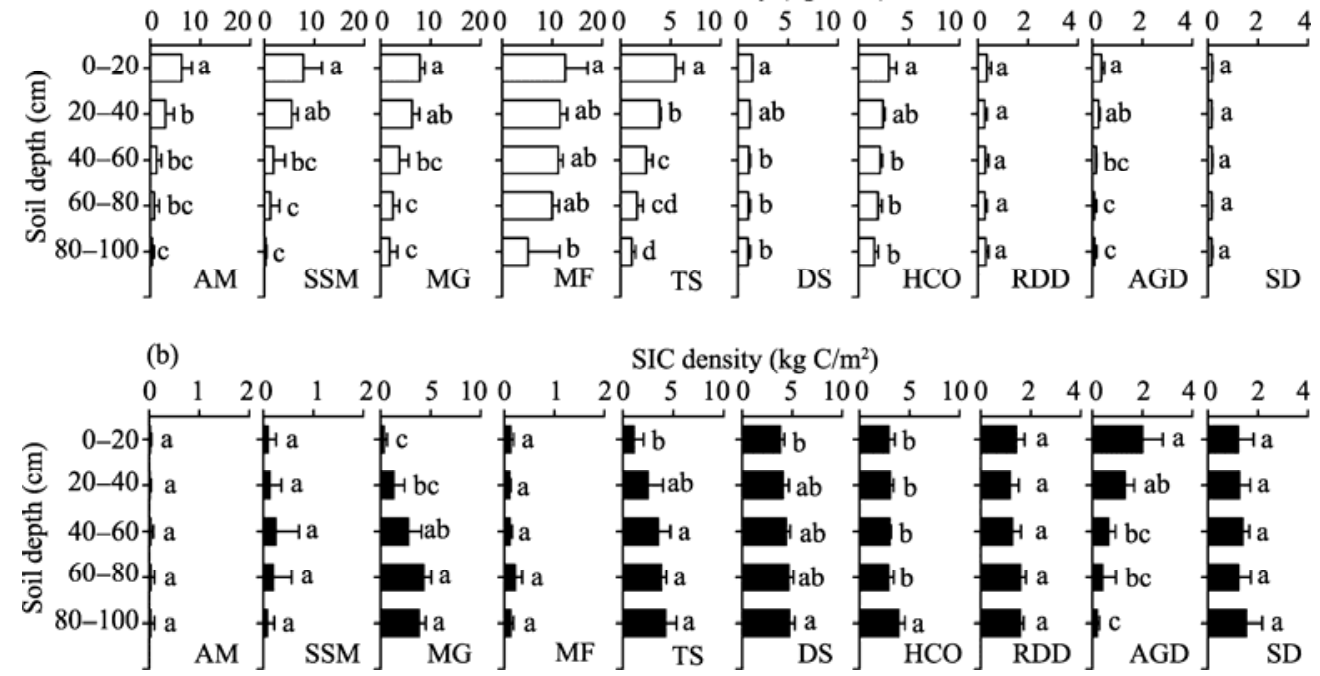

Fig. 3 Vertical distribution of (a) soil organic carbon (SOC) density and (b) soil inorganic carbon (SIC) density in the 10 representative landscapes of the HRB. Bars mean standard errors $(n=3)$. Different lowercase letters indicate significant differences at $P<0.05$ level among five depth intervals in each landscape.

\subsection{Soil organic and inorganic carbon storage in different landscapes}

Table 3 shows the mean values and standard deviations of SOC and SIC storage at the soil depths of $0-30,0-50$, and $0-100 \mathrm{~cm}$. There was a considerable variability in SOC storage and SIC storage at each soil depth across different landscapes (Table 3). SOC storage in the top meter ranged from $0.82 \mathrm{~kg} \mathrm{C} / \mathrm{m}^{2}$ in SD to $50.48 \mathrm{~kg} \mathrm{C} / \mathrm{m}^{2}$ in MF. The desert soils contained a low SOC storage (less than $0.5 \mathrm{~kg} \mathrm{C} / \mathrm{m}^{2}$ ) in the top $30 \mathrm{~cm}$ soil layer, while MF in forest stored up to 36 times that amount. The SIC storage at each soil depth (i.e., 0-30, 0-50, and 0-100 cm) was much higher in DS than in other landscapes $(P<0.05$; Table 3$)$. The SIC storage varied from 0.05 to 5.92 $\mathrm{kg} \mathrm{C} / \mathrm{m}^{2}$ in the $0-30 \mathrm{~cm}$ layer, from 0.08 to $10.14 \mathrm{~kg} \mathrm{C} / \mathrm{m}^{2}$ in the $0-50 \mathrm{~cm}$ layer, and from 0.19 to $21.91 \mathrm{~kg} \mathrm{C} / \mathrm{m}^{2}$ in the $0-100 \mathrm{~cm}$ layer. The ratio of SIC storage to STC (soil total carbon) storage generally increased with an increase in soil depth (Table 3). The STC storage in the top meter in MF $\left(51.20 \mathrm{~kg} \mathrm{C} / \mathrm{m}^{2}\right)$ was much higher than those $\left(<9 \mathrm{~kg} \mathrm{C} / \mathrm{m}^{2}\right)$ in the barren desert soils (e.g., $\mathrm{RDD}, \mathrm{AGD}$, and SD). The contribution of SIC to STC varied significantly across different landscapes (Fig. 4). The percentage of SIC storage in STC storage in AM, SSM, MG, and MF were much lower than those in TS, HCO, DS, RDD, AGD and SD (Fig. 4).

Table 3 Soil organic carbon (SOC) storage and soil inorganic carbon (SIC) storage and the ratio of SIC storage to soil total carbon (STC) storage at different soil depths in the 10 representative landscapes of the HRB

\begin{tabular}{|c|c|c|c|c|c|c|c|c|c|}
\hline \multirow{2}{*}{ Landscape } & \multicolumn{3}{|c|}{ SOC storage $\left(\mathrm{kg} \mathrm{C} / \mathrm{m}^{2}\right)$} & \multicolumn{3}{|c|}{ SIC storage $\left(\mathrm{kg} \mathrm{C} / \mathrm{m}^{2}\right)$} & \multicolumn{3}{|c|}{ SIC/STC ratio } \\
\hline & $0-30 \mathrm{~cm}$ & $0-50 \mathrm{~cm}$ & $0-100 \mathrm{~cm}$ & $0-30 \mathrm{~cm}$ & $0-50 \mathrm{~cm}$ & $0-100 \mathrm{~cm}$ & $0-30 \mathrm{~cm}$ & $0-50 \mathrm{~cm}$ & $0-100 \mathrm{~cm}$ \\
\hline $\mathrm{AM}$ & $7.94 \pm 1.98^{\mathrm{bc}}$ & $10.34 \pm 2.91^{\mathrm{cd}}$ & $11.76 \pm 3.14^{\mathrm{d}}$ & $0.05 \pm 0.02^{\mathrm{e}}$ & $0.08 \pm 0.04^{\mathrm{e}}$ & $0.19 \pm 0.19^{\mathrm{e}}$ & $0.01 \pm 0.00$ & $0.01 \pm 0.00$ & $0.02 \pm 0.01$ \\
\hline SSM & $10.89 \pm 4.75^{\mathrm{b}}$ & $14.42 \pm 3.62^{\mathrm{bc}}$ & $16.66 \pm 0.88^{c}$ & $0.17 \pm 0.24^{\mathrm{e}}$ & $0.40 \pm 0.62^{\mathrm{e}}$ & $0.81 \pm 1.30^{\mathrm{e}}$ & $0.03 \pm 0.04$ & $0.03 \pm 0.05$ & $0.04 \pm 0.07$ \\
\hline MG & $11.33 \pm 1.33^{\mathrm{b}}$ & $16.52 \pm 3.46^{\mathrm{b}}$ & $22.37 \pm 3.42^{\mathrm{b}}$ & $0.92 \pm 0.57^{\text {de }}$ & $2.86 \pm 2.19^{d}$ & $12.84 \pm 2.32^{\mathrm{c}}$ & $0.08 \pm 0.04$ & $0.15 \pm 0.13$ & 0.05 \\
\hline MF & $18.69 \pm 3.80^{\mathrm{a}}$ & $29.46 \pm 4.30^{\mathrm{a}}$ & $50.48 \pm 5.35^{\mathrm{a}}$ & $0.19 \pm 0.07^{\mathrm{e}}$ & $0.30 \pm 0.09^{\mathrm{e}}$ & $0.72 \pm 0.22^{\mathrm{e}}$ & $0.01 \pm 0.00$ & $0.01 \pm 0.00$ & $0.01 \pm 0.00$ \\
\hline TS & $7.68 \pm 0.79^{\mathrm{bc}}$ & $10.79 \pm 0.29^{c}$ & $14.73 \pm 1.14^{\mathrm{cd}}$ & $2.12 \pm 1.26^{\mathrm{cd}}$ & $5.61 \pm 2.97^{\mathrm{bc}}$ & $15.41 \pm 2.11^{\mathrm{b}}$ & 1 & 2 & .05 \\
\hline DS & $2.06 \pm 0.02^{\mathrm{de}}$ & $3.24 \pm 0.10^{\mathrm{ef}}$ & $5.83 \pm 0.59^{\mathrm{e}}$ & $5.92 \pm 0.62^{\mathrm{a}}$ & $10.14 \pm 1.10^{\mathrm{a}}$ & $21.91 \pm 1.61^{\mathrm{a}}$ & $0.74 \pm 0.02$ & $0.76 \pm 0.02$ & $0.79 \pm 0.03$ \\
\hline $\mathrm{HCO}$ & $4.30 \pm 0.85^{\text {cd }}$ & $6.58 \pm 1.03^{\mathrm{de}}$ & $11.10 \pm 1.93^{\mathrm{d}}$ & $4.56 \pm 0.68^{\mathrm{b}}$ & $7.72 \pm 0.89^{b}$ & $16.12 \pm 0.91^{\mathrm{b}}$ & $0.52 \pm 0.09$ & $0.54 \pm 0.07$ & $0.59 \pm 0.06$ \\
\hline $\mathrm{RDD}$ & $0.50 \pm 0.21^{\mathrm{de}}$ & $0.78 \pm 0.31^{\mathrm{f}}$ & $1.54 \pm 0.45^{\mathrm{f}}$ & $2.01 \pm 0.25^{\mathrm{cd}}$ & $3.26 \pm 0.34^{\mathrm{cd}}$ & $7.13 \pm 0.59^{\mathrm{d}}$ & $0.80 \pm 0.08$ & $0.81 \pm 0.07$ & $0.82 \pm 0.05$ \\
\hline AGD & $0.51 \pm 0.16^{\text {de }}$ & $0.70 \pm 0.16^{\mathrm{f}}$ & $0.95 \pm 0.06^{\mathrm{f}}$ & $2.81 \pm 1.14^{\mathrm{c}}$ & $3.74 \pm 1.11^{\mathrm{cd}}$ & $4.65 \pm 0.33^{\mathrm{d}}$ & $0.84 \pm 0.03$ & $0.84 \pm 0.02$ & $0.83 \pm 0.02$ \\
\hline SD & $0.25 \pm 0.01^{\mathrm{e}}$ & $0.42 \pm 0.03^{\mathrm{f}}$ & $0.82 \pm 0.06^{\mathrm{f}}$ & $1.88 \pm 0.80^{\mathrm{cd}}$ & $3.21 \pm 1.13^{\mathrm{cd}}$ & $6.74 \pm 2.27^{\mathrm{d}}$ & $0.87 \pm 0.05$ & $0.88 \pm 0.04$ & $0.88 \pm 0.04$ \\
\hline
\end{tabular}

Note: Mean \pm SE $(n=3)$. Values followed by different lowercase letters within a column are significantly different at $P<0.05$ level among different landscapes for the same soil depth. STC storage was the sum of SOC storage and SIC storage. 


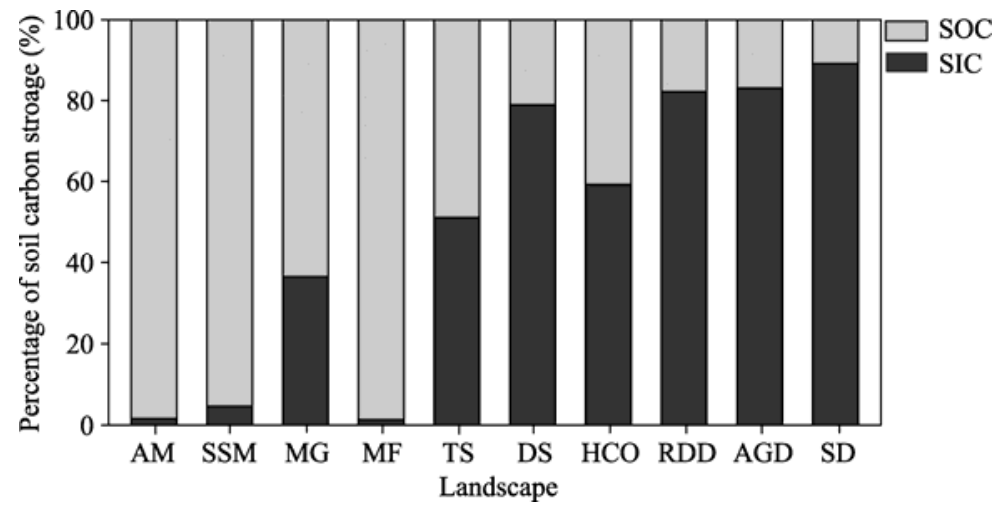

Fig. 4 Percentage of soil C storage in soil total carbon (STC) storage at the $0-100 \mathrm{~cm}$ soil depth in different landscapes. STC storage was the sum of SOC storage and SIC storage.

\subsection{Sr isotopic ratio in soil carbonate and its implications for PIC to SIC ratio}

The ${ }^{87} \mathrm{Sr} /{ }^{86} \mathrm{Sr}$ ratio in carbonate through the soil profiles showed a wider ranges from 0.710775 to 0.711762 and from 0.710965 to 0.711472 in MG and TS, respectively (Fig. 5). In comparison, a small variations of ${ }^{87} \mathrm{Sr} /{ }^{86} \mathrm{Sr}$ ratio in carbonate between genetic horizons were found in DS $(0.711063 \pm 0.000059)$ and HCO $(0.711982 \pm 0.000038)$ along their soil profiles (Fig. 5). Following the method of Chen et al. (1997), the calculated PIC stocks in the top meter of soils by Equations 2 and 4 were $7.23,10.74,15.50$ and $14.59 \mathrm{~kg} \mathrm{C} / \mathrm{m}^{2}$ in MG, TS, DS, and HCO, respectively. Correspondingly, the contributions of PIC storage to SIC storage were $71 \%, 80 \%, 76 \%$, and nearly $100 \%$ in these landscapes, respectively, demonstrating the significant role of pedogenic carbonate in the formation of SIC in the arid and semi-arid regions irrespective of the limited precipitation.

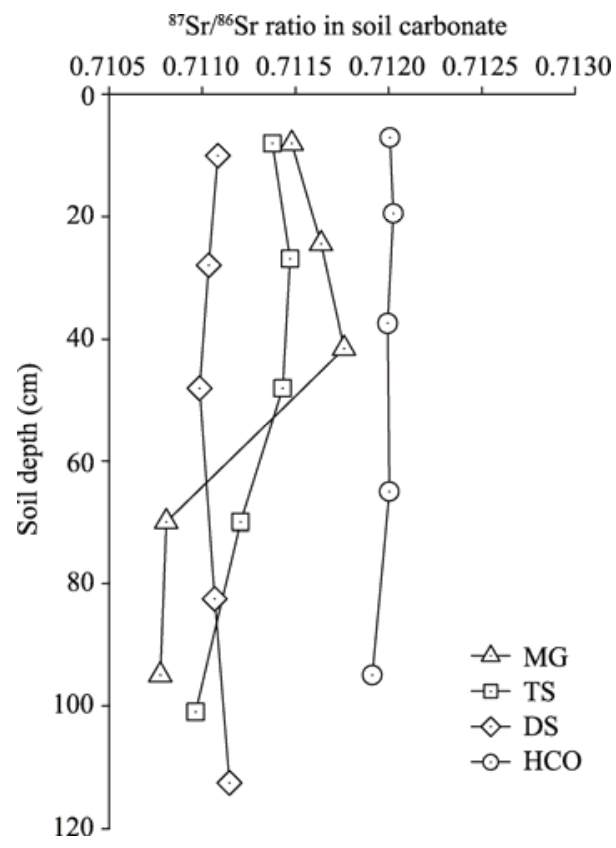

Fig. $5{ }^{87} \mathrm{Sr} /{ }^{86} \mathrm{Sr}$ ratio in soil carbonate along the selected soil profiles in MG, TS, DS and HCO

\subsection{Relationships between soil carbon storage and climatic factors}

SOC storage showed a positive correlation with MAP at different soil depths (i.e., 0-30, 0-50, and $0-100 \mathrm{~cm}$ ), but the coefficient of correlation decreased with increasing soil depth, suggesting a diminishing effect of MAP on SOC storage in the deeper layers as compared with the upper 
layer (Table 4). There were negative correlations between SOC storage $(0-30$ and $0-50 \mathrm{~cm})$ and AMT, and the coefficient of correlation also decreased with increasing soil depth (Table 4). In contrast, SIC storage showed an increasing trend with increasing AMT and decreasing MAP. However, there were no significant correlations between SIC storage and climatic factors, except a weak correlation between SIC storage at the 0-30 $\mathrm{cm}$ depth and AMT (Table 4).

Table 4 Correlations of SOC storage and SIC storage with mean annual precipitation (MAP) and annual mean temperature (AMT) at different soil depths

\begin{tabular}{cccccrrrr}
\hline & \multicolumn{3}{c}{ SOC storage } & & \multicolumn{3}{c}{ SIC storage } \\
\cline { 2 - 3 } \cline { 6 - 8 } & $0-30 \mathrm{~cm}$ & $0-50 \mathrm{~cm}$ & $0-100 \mathrm{~cm}$ & & $0-30 \mathrm{~cm}$ & $0-50 \mathrm{~cm}$ & $0-100 \mathrm{~cm}$ \\
\hline MAP & $0.82^{* *}$ & $0.80^{* *}$ & $0.68^{*}$ & & -0.61 & -0.47 & 0.22 \\
AMT & $-0.75^{*}$ & $-0.68^{*}$ & -0.54 & & $0.64^{*}$ & 0.53 & 0.35 \\
\hline
\end{tabular}

Note: ${ }^{*}$ and ${ }^{* *}$ mean significance at $P<0.05$ and $P<0.01$ levels, respectively.

\section{Discussion}

\subsection{Pedogenic interpretations for contrasting vertical distribution of soil organic and inorganic carbon in different landscapes}

The SOC density exhibited a decreasing trend with increasing soil depth in all landscapes in the HRB (Fig. 3a). The proportion of SOC density in the 0-20 cm layer relative to that in the top meter was the highest in AM (57\%) of the HRB, which is similar to the shallow SOC distribution in Tibetan alpine meadows (Table 5). This can be attributed to the dense roots in surface soils in the alpine meadow (Yang et al., 2010a). It is well known that vegetation, through patterns of above- and below-ground allocation, has an important effect on the vertical distribution of SOC (Jobbágy and Jackson, 2000). The percentage of SOC density in the top $20 \mathrm{~cm}$ layer in SSM (46\% of the total SOC density in the top meter) of the HRB was much higher than that reported in global shrublands (33\%; Table 5; Jobbágy and Jackson, 2000). This could be due to the root allocation in the shallow layers in subalpine ecosystems and shallow solum with limited addition of aeolian deposits (Fig. 2). In contrast, the percentage of SOC in the top $20 \mathrm{~cm}$ layer in MF (25\%) of the HRB was lower than that in global forests (50\%; Table 5) (Jobbágy and Jackson, 2000). The relatively high proportion of SOC in the deeper soil layers $(20-100 \mathrm{~cm})$ in MF could be caused by cryoturbation, which leads to the movement of SOM to the subsoils (Baumann et al., 2009; Liu et al., 2012). The percentage of SOC in the top $20 \mathrm{~cm}$ layer in MG (35\%) of the HRB was lower than that in global grasslands (42\%; Table 5). In the semi-arid steppe, the SOC density gradually decreased with increasing soil depth (Fig. 3a), which may be related to the deep root distribution in this zone. Compared to the average proportion of SOC in the subsoils of the croplands in China (63\%; Wang et al., 2004), the HCO of the HRB sequestered more SOC in the subsoils $(73 \%)$. This may be related to the deep incorporation of farmyard manure and crop residues during the progressive build-up of oases soils. Additionally, the leaching of organic matter and colloids along with irrigation has been found to move SOC from surface soils to the lower horizons in the drylands (Lal, 2004c). The lack of significant differences in SOC density at different soil depths in RDD and SD (Fig. 3a) reflects the homogeneous distribution of SOC in soil profiles in the extremely arid environments. However, the relatively high proportion of SOC density in the $0-20 \mathrm{~cm}$ layer relative to that in the top meter occurred in AGD (38\%) highlights the physical protection of fine particles in the surface soils of Gobi, which resulted in the resistance of organic matter to decompositions in these soils, in comparison with the situation in the relatively coarse subsoils (Fig. 2; Table 2).

The vertical distribution of SIC is in sharp contrast with the decreasing trend of SOC with increasing soil depth (Fig. 3). Specifically, AM, SSM, and MF are found mainly in high-altitude ecosystems, where intensive carbonate leaching is supposed to occur due to the relatively abundant precipitation and low temperature. Furthermore, the higher SOM content in these landscapes increases soil porosity through lowering the soil BD (Yang et al., 2014). This could in 
Table 5 Comparisons of vertical distribution and storage of soil organic and inorganic $\mathrm{C}$ in the HRB with previous estimates in other studies

\begin{tabular}{|c|c|c|c|c|c|}
\hline \multirow{2}{*}{ Type } & \multicolumn{2}{|c|}{$\begin{array}{c}\text { Vertical distribution } \\
\text { of soil C } \\
\end{array}$} & \multicolumn{2}{|c|}{$\begin{array}{l}\text { Soil C storage in the top meter } \\
\qquad\left(\mathrm{kg} \mathrm{C} / \mathrm{m}^{2}\right)\end{array}$} & \multirow[t]{2}{*}{ Reference } \\
\hline & $\mathrm{SOC}^{\mathrm{a}}$ & $\mathrm{SIC}^{\mathrm{b}}$ & SOC & SIC & \\
\hline \multicolumn{6}{|l|}{ Grassland } \\
\hline Global & $42 \%$ & - & $11.7-13.2$ & - & Jobbágy and Jackson (2000) \\
\hline China & $39 \%$ & B & $8.2,13.2$ & - & $\begin{array}{l}\text { Ni (2002); Wang et al. (2004); Yu et al. (2007); } \\
\text { Mi et al. (2008) }\end{array}$ \\
\hline $\mathrm{AM}(\mathrm{HRB})$ & $57 \%$ & $\mathrm{C}$ & 11.8 & 0.2 & This study \\
\hline Tibetan alpine meadow & $55 \%$ & - & $11.9-12.7,18.2$ & $11.7,13.5$ & Ni (2002); Yang et al. (2010a, b, c) \\
\hline $\begin{array}{l}\text { Alpine meadow } \\
\text { (Qinghai-Tibet Plateau) }\end{array}$ & - & - & $25.6(0-50 \mathrm{~cm}), 9.5$ & - & Wu et al. (2003a); Chen et al. (2016) \\
\hline MG (HRB) & $35 \%$ & $\mathrm{~B}$ & 22.4 & 12.8 & This study \\
\hline $\begin{array}{l}\text { Mountain grassland } \\
\text { (Qilian Mountains) }\end{array}$ & - & - & $\begin{array}{l}9.5-20.7(0-50 \mathrm{~cm}) \\
9.7-19.5(0-60 \mathrm{~cm})\end{array}$ & - & Chen et al. (2016); Zhu et al. (2017) \\
\hline Steppe (HRB) & $25 \%-38 \%$ & A & $5.8-14.7$ & $15.4-21.9$ & This study \\
\hline Tibetan alpine steppe & $41 \%$ & - & $7.4-14.9$ & 14.8 & Yang et al. $(2010 a, b)$ \\
\hline \multicolumn{6}{|l|}{ Shrubland } \\
\hline Global & $33 \%$ & - & 8.9 & - & Jobbágy and Jackson (2000) \\
\hline China & $46 \%$ & A & 11.5 & - & $\begin{array}{l}\text { Wang et al. (2004); Yu et al. (2007); Mi et al. } \\
\text { (2008) }\end{array}$ \\
\hline SSM (HRB) & $46 \%$ & $\mathrm{C}$ & 16.7 & 0.8 & This study \\
\hline $\begin{array}{l}\text { Mountain shrub } \\
\text { (Qilian Mountains) }\end{array}$ & - & - & $25.1-30.5(0-50 \mathrm{~cm})$ & - & Chen et al. (2016) \\
\hline \multicolumn{6}{|l|}{ Forestland } \\
\hline Global & $50 \%$ & - & $9.3-18.6$ & - & Jobbágy and Jackson (2000) \\
\hline China & $42 \%$ & A & 14.3 & - & $\begin{array}{l}\text { Yu et al. (2007); Yang et al. (2007); Mi et al. } \\
\text { (2008) }\end{array}$ \\
\hline MF (HRB) & $25 \%$ & $\mathrm{C}$ & 50.5 & 0.7 & This study \\
\hline Tibetan montane forest & $41 \%$ & - & - & - & Chang et al. (2015) \\
\hline $\begin{array}{l}\text { Alpine forest } \\
\text { (Qilian Mountains) }\end{array}$ & - & - & $\begin{array}{l}18.8-31.1(0-50 \mathrm{~cm}) \\
30.9-35.2(0-60 \mathrm{~cm})\end{array}$ & - & Chen et al. (2016); Zhu et al. (2017) \\
\hline \multicolumn{6}{|l|}{ Farmland } \\
\hline Global & $41 \%$ & - & 11.2 & - & Jobbágy and Jackson (2000) \\
\hline China & $34 \%$ & A & 9.2 & - & $\begin{array}{l}\text { Yang et al. (2007); Yu et al. (2007); Mi et al. } \\
\text { (2008) }\end{array}$ \\
\hline $\mathrm{HCO}(\mathrm{HRB})$ & $27 \%$ & A & 11.1 & 16.1 & This study \\
\hline $\begin{array}{l}\text { Irrigated farmland } \\
\text { (Xinjiang) }\end{array}$ & - & - & - & $16.6-17.1$ & Wu et al. (2009) \\
\hline \multicolumn{6}{|l|}{ Desert } \\
\hline Global & $33 \%$ & - & 6.2 & - & Jobbágy and Jackson (2000) \\
\hline China & $32 \%$ & $\mathrm{~B}$ & 2.9 & - & $\begin{array}{l}\text { Yang et al. (2007); Yu et al. (2007); Mi et al. } \\
\text { (2008) }\end{array}$ \\
\hline Deserts (HRB) & $22 \%-38 \%$ & $\mathrm{~A}, \mathrm{D}$ & $0.8-1.5$ & $4.7-7.1$ & This study \\
\hline Gobi (Northwest China) & - & - & $0.7(0-40 \mathrm{~cm})$ & - & Zhang and Shao (2014) \\
\hline Desert (Hexi Corridor) & $3 \%$ & - & - & - & Wang et al. (2014) \\
\hline Desert (Inner Mongolia) & - & - & 5.7 & 0.1 & Wang et al. (2013) \\
\hline
\end{tabular}

Note: a, vertical distribution pattern of SOC was expressed by the proportion of SOC density in the $0-20 \mathrm{~cm}$ layer relative to that in the top meter; ${ }^{b}$, A represents that SIC content increases with increasing depth, B represents that SIC content peaks at intermediate depths, C represents that SIC content shows mixed patterns with increasing depth, and D represents that SIC content decreases with increasing depth. -, no data.

part favor carbonate leaching in forest soils. As a consequence, low SIC density values $(<1 \mathrm{~kg}$ $\mathrm{C} / \mathrm{m}^{2}$ ) throughout the soil profiles were found in these landscapes (Fig. 3b). The enrichment of SIC in the deeper soils of grasslands (e.g., MG and TS; Fig. 3b) was attributed to the dissolution and leaching of carbonates from their topsoil and the subsequent precipitation in the subsoil. This is in accordance with the SIC distribution patterns of grasslands in China reported by Mi et al. 
(2008). However, relatively less carbonate leaching has occurred in the soil profile of DS due to the low precipitation (MAP, $144 \mathrm{~mm}$ ). The homogeneous distribution of SIC in the $0-80 \mathrm{~cm}$ soil layers in HCO may be associated with the continuous supply of $\mathrm{Ca}^{2+}$ and/or $\mathrm{Mg}^{2+}$ by irrigation and limited carbonate leaching in developing agricultural oases (Gong et al., 1999). Since barely any percolating water is available for the migration of SIC in the hyper-arid desert ecosystems, parent material might play a major role in shaping the vertical distribution of SIC density for RDD, SD, and AGD. The soils of RDD and SD were respectively derived from uniform fine alluvium and aeolian sands (Fig. 2), leading to the homogeneous distribution of SIC in both landscapes. However, the soils of AGD, which were characterized by fine aeolian deposit rich in carbonates overlying the coarse alluvium (Table 1; Fig. 2), exhibited a high percentage of SIC in the top $20 \mathrm{~cm}$ layer relative to that in the top meter (43\%; Fig. $3 \mathrm{~b}$ ).

\subsection{Controlling factors for soil organic and inorganic carbon storage in different landscapes}

There was a considerable spatial variability in SOC storage across different landscapes in the HRB. Higher SOC storage was observed in high-altitude ecosystems due to the relatively high precipitation and biomass production. The highest SOC storage was observed in Picea crassifolia forest (MF), which stored more than $50 \mathrm{~kg} \mathrm{C} / \mathrm{m}^{2}$ in the top meter (Table 3). The SOC storage of MF at the 0-60 cm depth was comparable to values reported under the same plant species and similar climate conditions (Zhu et al., 2017). In this study, we found a relatively low SOC storage $\left(11.76 \mathrm{~kg} \mathrm{C} / \mathrm{m}^{2}\right)$ in $\mathrm{AM}$, which was much lower than that of in Xishui Forest Reserve (Table 5) in the Qilian Mountains but was higher than the average of alpine meadow $\left(8.70 \mathrm{~kg} \mathrm{C} / \mathrm{m}^{2}\right)$ in the northeastern margin of the Tibetan Plateau (Chen et al., 2016). These differences could be an effect of the considerable spatial heterogeneity across the Qilian Mountains. Although the vegetation type was uniform, climate conditions and soil types were very different, thus playing an important role in determining the SOC stocks (Liu et al., 2012). The desert soils (RDD, AGD, and SD) in the HRB showed the lower SOC storage across the climate transect due to the extremely arid climate and low biotic activity. As shown in Table 5, the SOC storage in desert soils in our study was similar to that reported in Gobi desert soils (Table 5) by Zhang and Shao (2014), but was much lower than the average SOC storage (Table 5) for global desert soils (Jobbágy and Jackson, 2000). In the HRB, higher SOC storage was found in HCO as compared with that in desert soils, which was attributed to irrigation and fertilization, both enhancing biomass production. Overall, the SOC storage in different landscapes generally increased with increasing precipitation and decreased with increasing temperature, as evidenced by the correlation analyses (Table 4). In drought-prone ecosystems, even a small amount increase of precipitation can significantly stimulate plant production and thus contribute to the accumulation of SOC (Wu et al., 2003b). Wang et al. (2015) also demonstrated that precipitation is the limiting factor of SOC accumulation in the arid and semi-arid regions of Northwest China. The high spatial variability of SOC storage in different landscapes in the HRB had important implications for ecosystem function and security due to their different sensitivities to climate change. Our results also highlighted that an accurate estimation of SOC storage in the arid and semi-arid regions of Northwest China should consider the large variations of SOC storage in the diverse ecosystems under different landscapes.

Carbonates have generally been regarded as the most common form of soil $\mathrm{C}$ in the arid and semi-arid regions (Lal, 2004c; Mi et al., 2008; Monger, 2014), yet little information is available on SIC distribution in the HRB. The SIC storage also exhibited large variations across different landscapes in this basin. The highest SIC storage occurred in DS (Table 3), due to the arid environment together with aeolian deposit rich in $\mathrm{CaCO}_{3}$ (Wu et al., 2009). In contrast, the high mountain areas (e.g., AM, SSM, and MF) showed a very low SIC storage, which can be attributed to the carbonate leaching facilitated by the relative high precipitation. In addition, relatively high SIC storage $\left(16.12 \mathrm{~kg} \mathrm{C} / \mathrm{m}^{2}\right)$ in the top meter was found in HCO due to build-up of siltigation rich in carbonate by means of long history of irrigation (Gong et al., 1999). This storage was similar to that of irrigated desert soils $\left(16.6 \mathrm{~kg} \mathrm{C} / \mathrm{m}^{2}\right)$ and irrigated silting soils $\left(17.1 \mathrm{~kg} \mathrm{C} / \mathrm{m}^{2}\right)$ in China $(\mathrm{Wu}$ 
et al., 2009). Overall, there were no significant relationships between SIC storage and climatic factors (Table 4). Previous studies have demonstrated that SIC storage is mainly determined by soil parent material and climate (Mi et al., 2008; Wu et al., 2009). The large variations of SIC in our study also reflect the differences in parent material and the varying degree of leaching and/or calcification of soils. The SIC storage in the arid regions with precipitation less than $200 \mathrm{~mm}$ was highest in loess (DS), followed by siltigation (HCO), aeolian deposition (surface soil of AGD), alluvium (RDD), and aeolian sand (SD; Fig. 6). This indicates that soil parent material is the primary control of SIC storage in the hyper-arid environments due to limited leaching of carbonate (Wu et al., 2009). Moreover, SIC storage at each depth interval was positively correlated with AMT and negatively correlated with MAP (Fig. 7) in the Qilian Mountains where soils were derived from aeolian deposits, suggesting climatic factors are important drivers of SIC variations in these landscapes (AM, SSM, MG, MF, TS, and DS). Furthermore, the estimated PIC stocks of MG, TS, DS and HCO accounted for more than $70 \%$ of total SIC. The highest proportion of PIC relative to SIC occurred in $\mathrm{HCO}$ due to the abundant irrigation water that favored dissolution, translocation and precipitation of $\mathrm{CaCO}_{3}$. The PIC accumulation rate in the top meter is $0.6,0.9$, and $1.3 \mathrm{~g} \mathrm{C} /\left(\mathrm{m}^{2} \cdot \mathrm{a}\right)$ in $\mathrm{MG}$, TS, and DS, respectively, if it is assumed that all the carbonates are derived from the Holocene loess (Küster et al., 2006). The low PIC accumulation rate in our study agreed well with the results concluded by Scharpenseel et al. (2000) and Landi et al. (2003), who reported that the PIC accumulation rate was less than $3 \mathrm{~g} \mathrm{C} /\left(\mathrm{m}^{2} \cdot \mathrm{a}\right)$ in the arid and semi-arid regions of Canada, USA and New Zealand.

In general, the contrasting landscapes in the HRB lead to greatly different distribution patterns of SOC and SIC storage, and there is a general trade-off between SOC and SIC stocks. This compensatory effect of environmental conditions, especially climate, on SOC and SIC formation can be largely attributed to the fact that the overall decrease in temperature and increase in precipitation from arid deserts to alpine mountains facilitate the accumulation of SOC and depletion of SIC simultaneously. Further, a better understanding of the counterbalance between SOC and SIC would improve the estimation of different $\mathrm{C}$ pools and $\mathrm{C}$ budgets at watershed scales, especially for the arid inland river basins.

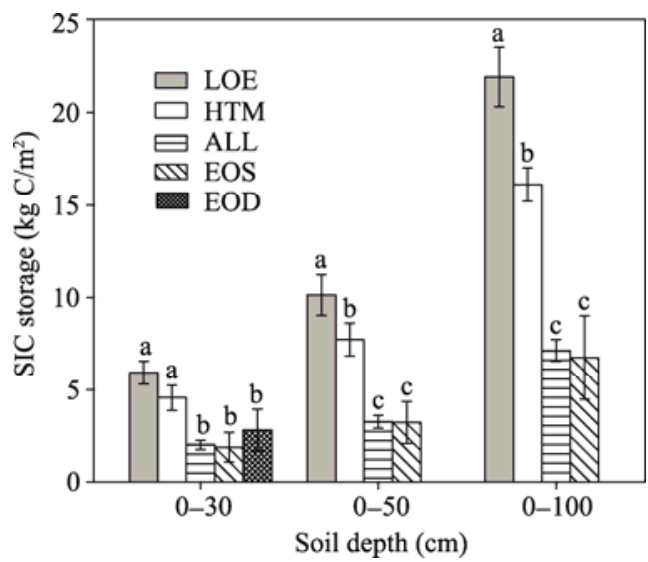

Fig. 6 SIC storage at three soil depths in regions with mean annual precipitation less than $200 \mathrm{~mm}$. LOE, loess (DS); HTM, human-transported material (siltigation; HCO); ALL, alluvium (RDD); EOS, aeolian sand (SD); EOD, aeolian deposit (surface soil of AGD). Different lowercase letters indicate statistical significance at $P<0.05$ level among various parent materials for the same soil depth. Bars mean standard deviations.

\section{Conclusions}

We assessed the influences of climate regimes, parent materials and vegetation characteristics on SOC and SIC storage and their vertical distribution patterns in 10 representative landscapes in the inland Heihe River Basin (HRB), Northwest China. The large observed variations in SOC storage 

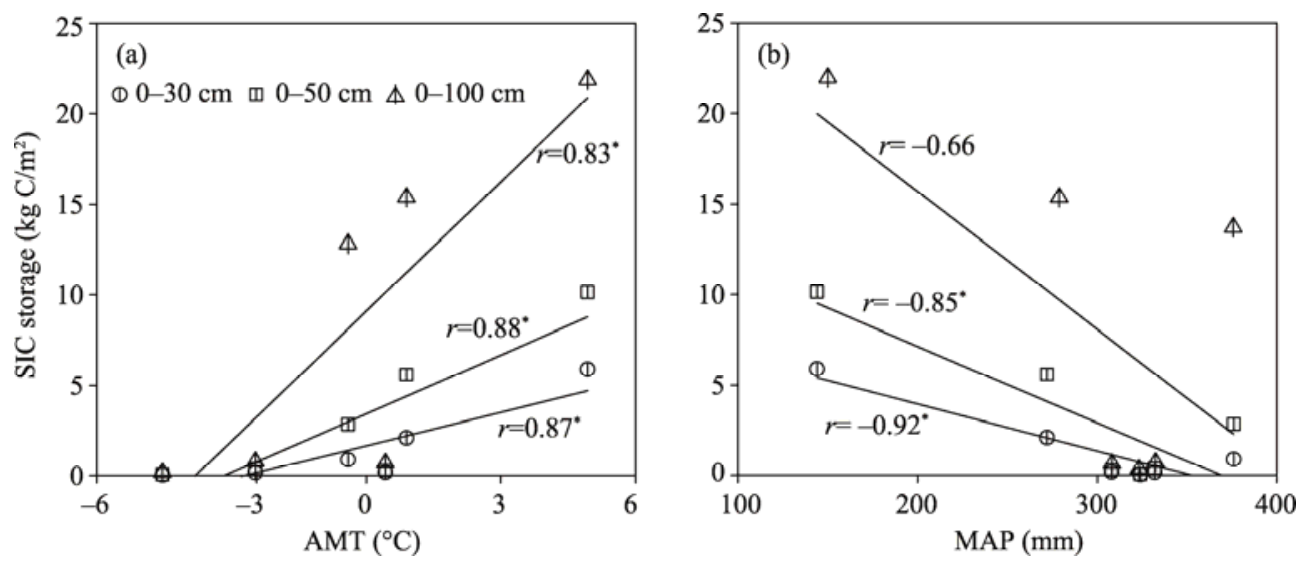

Fig. 7 Relationships between SIC storage at different soil depths with (a) annual mean temperature (AMT) and (b) mean annual precipitation (MAP) in the Qilian Mountains where soils were derived from aeolian deposits. ${ }^{*}$ means significance at $P<0.05$ level.

reflect the very different climatic conditions in different landscapes, which together with the corresponding vegetation types, strongly determines the profile distribution. The distribution pattern of SIC exhibited more complicated variations than SOC along soil profiles in different landscapes in relation to leaching intensity and parent materials at the local sites. Generally, the SIC contributed more than $75 \%$ of total C pool when SOC storage was lower than $10 \mathrm{~kg} \mathrm{C} / \mathrm{m}^{2}$ in the top meter, suggesting a threshold when SIC cannot be neglected in quantifying $\mathrm{C}$ pools in the HRB. Furthermore, the ${ }^{87} \mathrm{Sr} /{ }^{86} \mathrm{Sr}$ ratio in soil carbonate proved to be an effective method for distinguishing pedogenic and lithologic inorganic C, and PIC accounted for more than $70 \%$ of total SIC storage in the selected landscapes, demonstrating the significant role of pedogenic carbonate in the arid and semi-arid regions, irrespective of the limited precipitation. The considerable variations of SOC and SIC in different landscapes were attributed to pedogenic forces resulting from contrasting climatic regimes, parent materials and vegetation types. There is a general trade-off pattern between SOC and SIC storage across the contrasting landscapes in the HRB due to the changing processes facilitating the accumulation of SOC or SIC in this area.

\section{Acknowledgements}

This study was supported by the National Natural Science Foundation of China (91325301, 41130530, 41371224, 41601221). We are grateful to two anonymous reviewers for their constructive comments. We also thank David G ROSSITER, Cornell University and ISRIC-World Soil Information for language polishing.

\section{References}

Batjes N H. 1996. Total carbon and nitrogen in the soils of the world. European Journal of Soil Science, 47(2): 151-163.

Baumann F, He J S, Schmidt K, et al. 2009. Pedogenesis, permafrost, and soil moisture as controlling factors for soil nitrogen and carbon contents across the Tibetan Plateau. Global Change Biology, 15(12): 3001-3017.

Bughio M A, Wang P L, Meng F Q, et al. 2016. Neoformation of pedogenic carbonates by irrigation and fertilization and their contribution to carbon sequestration in soil. Geoderma, 262: 12-19.

Chang R Y, Fu B J, Liu G H, et al. 2012. The effects of afforestation on soil organic and inorganic carbon: a case study of the Loess Plateau of China. CATENA, 95(3): 145-152.

Chang R Y, Wang G X, Fei R, et al. 2015. Altitudinal change in distribution of soil carbon and nitrogen in Tibetan montane forests. Soil Science Society of America Journal, 79(5): 1455-1469.

Chen J, Qiu G, Yang J D. 1997. Sr isotopic composition of loess carbonate and identification of primary and secondary carbonates. Progress in Natural Science, 7(5): 590-593.

Chen L F, He Z B, Du J, et al. 2016. Patterns and environmental controls of soil organic carbon and total nitrogen in alpine ecosystems of northwestern China. CATENA, 137: 37-43.

Cheng G D, Li X, Zhao W Z, et al. 2014. Integrated study of the water-ecosystem-economy in the Heihe River Basin. National 
Science Review, 1(3): 413-428.

Eswaran H, Van Den Berg E, Reich P F, et al. 1995. Global soil carbon resources. In: Lal R, Kimble J M, Levine E, et al. Soils and Global Change. Boca Raton, FL, USA: CRC Press, 27-43.

Eswaran H, Reich P F, Kimble J M, et al. 2000. Global carbon stocks. In: Lal R, Kimble J M, Eswaran H, et al. Global Climate Change and Pedogenic Carbonates. Boca Raton, FL, USA: CRC Press, 15-25.

Gong Z T, et al. 1999. Chinese Soil Taxonomy. Beijing: Science Press, 136. (in Chinese)

IUSS Working Group. 2014. World Reference Base for Soil Resources 2014: international soil classification system for naming soils and creating legends for soil maps. In: World Soil Resources Reports No. 106. FAO, Rome.

Jobbágy E G, Jackson R B. 2000. The vertical distribution of soil organic carbon and its relation to climate and vegetation. Ecological Applications, 10(2): 423-436.

Kang E, Lu L, Xu Z. 2007. Vegetation and carbon sequestration and their relation to water resources in an inland river basin of Northwest China. Journal of Environmental Management, 85(3): 702-710.

Küster Y, Hetzel R, Krbetschek M, et al. 2006. Holocene loess sedimentation along the Qilian Shan (China): significance for understanding the processes and timing of loess deposition. Quaternary Science Reviews, 25(1-2): 114-125.

Lal R. 2004a. Soil carbon sequestration to mitigate climate change. Geoderma, 123(1-2): 1-22.

Lal R. 2004b. Soil carbon sequestration impacts on global climate change and food security. Science, 304(5677): $1623-1627$.

Lal R. 2004c. Carbon sequestration in dryland ecosystems. Environmental Management, 33(4): 528-544.

Landi A, Mermut A R, Anderson D W. 2003. Origin and rate of pedogenic carbonate accumulation in Saskatchewan soils, Canada. Geoderma, 117(1-2): 143-156.

Li C F, Zhang C, Luo G P, et al. 2015. Carbon stock and its responses to climate change in Central Asia. Global Change Biology, 21(5): 1951-1967.

Li D F, Shao M A. 2014. Soil organic carbon and influencing factors in different landscapes in an arid region of northwestern China. CATENA, 116: 95-104.

Liu W G, Wei J, Cheng J M, et al. 2014. Profile distribution of soil inorganic carbon along a chronosequence of grassland restoration on a 22-year scale in the Chinese Loess Plateau. CATENA, 121(7): 321-329.

Liu W J, Chen S Y, Qin X, et al. 2012. Storage, patterns, and control of soil organic carbon and nitrogen in the northeastern margin of the Qinghai-Tibetan Plateau. Environmental Research Letters, 7(3): 035401.

Lü Y H, Ma Z M, Zhao Z J, et al. 2014. Effects of land use change on soil carbon storage and water consumption in an oasis-desert ecotone. Environmental Management, 53(6): 1066-1076.

Mi N, Wang S Q, Liu J Y, et al. 2008. Soil inorganic carbon storage pattern in China. Global Change Biology, 14(10): 2380-2387.

Monger H C, Martinez-Rios J J. 2000. Inorganic carbon sequestration in grazing lands. In: Follett R F, Kimble J M, Lal R. The Potential of U.S. Grazing Lands to Sequester Carbon and Mitigate the Greenhouse Effect. Boca Raton, FL, USA: Lewis Publisher, 87-118.

Monger H C. 2014. Soils as generators and sinks of inorganic carbon in geologic time. In: Hartemink A E, McSweeney K. Soil Carbon. Cham, Switzerland: Springer, 27-36.

Monger H C, Kraimer R A, Khresat S, et al. 2015. Sequestration of inorganic carbon in soil and groundwater. Geology, 43(5): 375-378.

Nelson D W, Sommers L E. 1982. Total carbon, organic carbon, and organic matter. In: Page A L, Miller R H, Keeney D R. Methods of Soils Analysis. Part 2. Chemical and Microbiological Properties (2 ${ }^{\text {nd }}$ ed.). Madison, WI: American Society of Agronomy, 539-579.

Ni J. 2002. Carbon storage in grasslands of China. Journal of Arid Environments, 50(2): 205-218.

Qin J, Ding T J, Wu J K, et al. 2013. Understanding the impact of mountain landscapes on water balance in the upper Heihe River watershed in northwestern China. Journal of Arid Land, 5(3): 366-383.

Scharpenseel H W, Mtimet A, Freytag J, et al. 2000. Soil inorganic carbon and global change. In: Lal R, Kimble J M, Eswaran H, et al. Global Climate Change and Pedogenic Carbonates. Boca Raton, FL, USA: CRC Press, 27-42.

Schlesinger W H. 1997. Biogeochemistry: An Analysis of Global Change (2 $2^{\text {nd }}$ ed.). San Diego, CA, USA: Academic Press, 588. Schlesinger W H. 2017. An evaluation of abiotic carbon sinks in deserts. Global Change Biology, 23(1): 25-27.

Schoeneberger P J, Wysocki D A, Benham E C, et al. 2012. Field Book for Describing and Sampling Soils, Version 3.0. Lincoln, NE: Natural Resources Conservation Service, National Soil Survey Center.

Su Y Z, Wang J Q, Yang R, et al. 2015. Soil texture controls vegetation biomass and organic carbon storage in arid desert grassland in the middle of Hexi Corridor region in Northwest China. Soil Research, 53(4): 366-376.

Trumbore S E, Czimczik C I. 2008. An uncertain future for soil carbon. Science, 321(5895): 1455-1456. 
Wang G X, Yao J Z, Luo L, et al. 2004. Soil C and N content under evolving landscapes in an arid inland river basin of Northwest China. Landscape Ecology, 19(6): 621-629.

Wang G X, Liu J Q, Kubota J, et al. 2007. Effects of land-use changes on hydrological processes in the middle basin of the Heihe River, northwest China. Hydrological Processes, 21(10): 1370-1382.

Wang J P, Wang X J, Zhang J, et al. 2015. Soil organic and inorganic carbon and stable carbon isotopes in the Yanqi Basin of northwestern China. European Journal of Soil Science, 66(1): 95-103.

Wang M, Su Y Z, Yang X. 2014. Spatial distribution of soil organic carbon and its influencing factors in desert grasslands of the Hexi Corridor, northwest China. PLoS ONE, 9(4): e94652.

Wang S Q, Huang M, Shao X M, et al. 2004. Vertical distribution of soil organic carbon in China. Environmental Management, 33(Suppl.): S200-S209.

Wang S Q, Yu G R, Zhao Q J, et al. 2005. Spatial characteristics of soil organic carbon storage in China's croplands. Pedosphere, 15(4): 417-423.

Wang X J, Wang J P, Xu M G, et al. 2015. Carbon accumulation in arid croplands of northwest China: pedogenic carbonate exceeding organic carbon. Scientific Reports, 5: 11439.

Wang Y G, Li Y, Ye X H, et al. 2010. Profile storage of organic/inorganic carbon in soil: from forest to desert. Science of the Total Environment, 408(8): 1925-1931.

Wang Z P, Han X G, Chang S X, et al. 2013. Soil organic and inorganic carbon contents under various land uses across a transect of continental steppes in Inner Mongolia. CATENA, 109(10): 110-117.

West L T, Drees L R, Wilding L P, et al. 1988. Differentiation of pedogenic and lithogenic carbonate forms in Texas. Geoderma, 43(2-3): 271-287.

Wu H B, Guo Z T, Peng C H. 2003a. Distribution and storage of soil organic carbon in China. Global Biogeochemical Cycles, 17(2): 1048, doi: 10.1029/2001GB001844.

Wu H B, Guo Z T, Peng C H. 2003b. Land use induced changes of organic carbon storage in soils of China. Global Change Biology, 9(3): 305-315.

Wu H B, Guo Z T, Gao Q, et al. 2009. Distribution of soil inorganic carbon storage and its changes due to agricultural land use activity in China. Agriculture, Ecosystems \& Environment, 129(4): 413-421.

Wynn J G, Bird M I, Vellen L, et al. 2006. Continental-scale measurement of the soil organic carbon pool with climatic, edaphic, and biotic controls. Global Biogeochemical Cycles, 20(1): GB1007.

Yang F, Zhang G L, Yang J L, et al. 2014. Organic matter controls of soil water retention in an alpine grassland and its significance for hydrological processes. Journal of Hydrology, 519: 3086-3093.

Yang F, Huang L M, Rossiter D G, et al. 2017. Evolution of loess-derived soil along a climatic toposequence in the Qilian Mountains, NE Tibetan Plateau. European Journal of Soil Science, 68(3): 270-280.

Yang R M, Zhang G L, Liu F, et al. 2016. Comparison of boosted regression tree and random forest models for mapping topsoil organic carbon concentration in an alpine ecosystem. Ecological Indicators, 60: 870-878.

Yang Y H, Mohammat A, Feng J M, et al. 2007. Storage, patterns and environmental controls of soil organic carbon in China. Biogeochemistry, 84(2): 131-141.

Yang Y H, Fang J Y, Guo D L, et al. 2010a. Vertical patterns of soil carbon, nitrogen and carbon: nitrogen stoichiometry in Tibetan grasslands. Biogeosciences Discussions, 7(1): 1-24.

Yang Y H, Fang J Y, Ji C J, et al. 2010b. Soil inorganic carbon stock in the Tibetan alpine grasslands. Global Biogeochemical Cycles, 24(4): GB4022.

Yang Y H, Fang J Y, Ma W H, et al. 2010c. Soil carbon stock and its changes in northern China's grasslands from 1980s to 2000s. Global Change Biology, 16(11): 3036-3047.

Yin D Q, Li X, Huang Y F, et al. 2015. Identifying vegetation dynamics and sensitivities in response to water resources management in the Heihe River Basin in China. Advances in Meteorology, 2015: 861928.

Yu D S, Shi X Z, Wang H J, et al. 2007. Regional patterns of soil organic carbon stocks in China. Journal of Environmental Management, 85(3): 680-689.

Zhang F, Wang X J, Guo T W, et al. 2015. Soil organic and inorganic carbon in the loess profiles of Lanzhou area: implications of deep soils. CATENA, 126: 68-74.

Zhang P P, Shao M A. 2014. Spatial variability and stocks of soil organic carbon in the Gobi desert of Northwestern China. PLoS ONE, 9(4): e93584.

Zhu M, Feng Q, Qin Y Y, et al. 2017. Soil organic carbon as functions of slope aspects and soil depths in a semiarid alpine region of Northwest China. CATENA, 152: 94-102. 


\section{Appendix}

Table S1 Characteristics of sampling sites across the 10 representative landscape types in the Heihe River Basin

\begin{tabular}{|c|c|c|c|c|c|c|}
\hline Site & Latitude & Longitude & Altitude (m) & Horizon & Depth $(\mathrm{cm})$ & Gravel (\%) \\
\hline \multirow[t]{5}{*}{ AM01 } & $38.62380^{\circ} \mathrm{N}$ & $98.38472^{\circ} \mathrm{E}$ & 4179 & $\mathrm{Ah}$ & $0-10$ & 15 \\
\hline & & & & $\mathrm{AB}$ & $10-23$ & 15 \\
\hline & & & & $\mathrm{Bw}$ & $23-43$ & 30 \\
\hline & & & & $2 \mathrm{C} 1$ & $43-75$ & 80 \\
\hline & & & & $2 \mathrm{C} 2$ & $75-100$ & 80 \\
\hline \multirow[t]{3}{*}{ AM02 } & $38.228381^{\circ} \mathrm{N}$ & $99.89638^{\circ} \mathrm{E}$ & 3887 & Oi & $0-12$ & 10 \\
\hline & & & & $\mathrm{Ah}$ & $12-24$ & 40 \\
\hline & & & & $2 \mathrm{C}$ & $24-100$ & 85 \\
\hline \multirow[t]{3}{*}{ AM03 } & $38.37852^{\circ} \mathrm{N}$ & $99.32063^{\circ} \mathrm{E}$ & 3630 & Oi & $0-20$ & 8 \\
\hline & & & & $\mathrm{Bw}$ & $20-47$ & 10 \\
\hline & & & & $2 \mathrm{C}$ & $47-100$ & 85 \\
\hline \multirow[t]{4}{*}{ SSM01 } & $38.23413^{\circ} \mathrm{N}$ & $99.89186^{\circ} \mathrm{E}$ & 3682 & $\mathrm{Ah}$ & $0-14$ & 5 \\
\hline & & & & Bw & $14-35$ & 5 \\
\hline & & & & $2 \mathrm{C} 1$ & $35-57$ & 80 \\
\hline & & & & $2 \mathrm{C} 2$ & $57-100$ & 80 \\
\hline \multirow[t]{4}{*}{ SSM02 } & $38.23992^{\circ} \mathrm{N}$ & $99.88897^{\circ} \mathrm{E}$ & 3539 & $\mathrm{Ah}$ & $0-20$ & 5 \\
\hline & & & & $\mathrm{Bw}$ & $20-42$ & 5 \\
\hline & & & & $2 \mathrm{C} 1$ & $42-65$ & 75 \\
\hline & & & & $2 \mathrm{C} 2$ & $65-100$ & 85 \\
\hline \multirow[t]{4}{*}{ SSM03 } & $38.25151^{\circ} \mathrm{N}$ & $99.89244^{\circ} \mathrm{E}$ & 3304 & $\mathrm{Ah}$ & $0-18$ & 3 \\
\hline & & & & $\mathrm{AB}$ & $18-38$ & 8 \\
\hline & & & & $\mathrm{Bw}$ & $38-74$ & 8 \\
\hline & & & & $2 \mathrm{C}$ & $74-100$ & 55 \\
\hline \multirow[t]{5}{*}{ MG01 } & $37.89275^{\circ} \mathrm{N}$ & $100.75169^{\circ} \mathrm{E}$ & 3412 & Oi & $0-16$ & 0 \\
\hline & & & & $\mathrm{Ah}$ & $16-33$ & 0 \\
\hline & & & & $\mathrm{AB}$ & $33-50$ & 0 \\
\hline & & & & $\mathrm{Bk}$ & $50-90$ & 15 \\
\hline & & & & $\mathrm{BC}$ & $90-100$ & 30 \\
\hline \multirow[t]{6}{*}{ MG02 } & $38.01492^{\circ} \mathrm{N}$ & $100.62564^{\circ} \mathrm{E}$ & 3114 & $\mathrm{Ah}$ & $0-14$ & 0 \\
\hline & & & & $\mathrm{AB}$ & $14-42$ & 0 \\
\hline & & & & Bk1 & $42-63$ & 0 \\
\hline & & & & $\mathrm{Bk} 2$ & $63-80$ & 0 \\
\hline & & & & $\mathrm{C} 1$ & $80-113$ & 0 \\
\hline & & & & $\mathrm{C} 2$ & $113-120$ & 0 \\
\hline \multirow[t]{5}{*}{ MG03 } & $38.02241^{\circ} \mathrm{N}$ & $100.62860^{\circ} \mathrm{E}$ & 3109 & $\mathrm{Ah}$ & $0-15$ & 0 \\
\hline & & & & $\mathrm{AB}$ & $15-33$ & 0 \\
\hline & & & & $\mathrm{Bk}$ & $33-60$ & 0 \\
\hline & & & & $2 \mathrm{Ab}$ & $60-90$ & 2 \\
\hline & & & & $2 \mathrm{Bkb}$ & $90-110$ & 2 \\
\hline \multirow[t]{4}{*}{ MF01 } & $38.26608^{\circ} \mathrm{N}$ & $99.89329^{\circ} \mathrm{E}$ & 3056 & Oi & $0-15$ & 0 \\
\hline & & & & $\mathrm{Ah}$ & $15-37$ & 0 \\
\hline & & & & $\mathrm{Bw}$ & $37-65$ & 0 \\
\hline & & & & $2 \mathrm{C}$ & $65-78$ & 20 \\
\hline \multirow[t]{7}{*}{ MF02 } & $38.15239^{\circ} \mathrm{N}$ & $100.25036^{\circ} \mathrm{E}$ & 3004 & Oi & $0-6$ & 0 \\
\hline & & & & Ah1 & $6-14$ & 0 \\
\hline & & & & Ah2 & $14-24$ & 0 \\
\hline & & & & $\mathrm{AB}$ & $24-40$ & 0 \\
\hline & & & & Bh1 & $40-53$ & 0 \\
\hline & & & & $\mathrm{Bh} 2$ & $53-75$ & 0 \\
\hline & & & & $\mathrm{Bh} 3$ & $75-100$ & 0 \\
\hline
\end{tabular}




\begin{tabular}{|c|c|c|c|c|c|c|}
\hline & & & & & & Continued \\
\hline Site & Latitude & Longitude & Altitude (m) & Horizon & Depth $(\mathrm{cm})$ & Gravel (\%) \\
\hline \multirow[t]{2}{*}{ MF02 } & $38.15239^{\circ} \mathrm{N}$ & $100.25036^{\circ} \mathrm{E}$ & 3004 & $\mathrm{Bh} 4$ & $100-110$ & 0 \\
\hline & & & & $\mathrm{Cjj}$ & $110-120$ & 0 \\
\hline \multirow[t]{6}{*}{ MF03 } & $38.11737^{\circ} \mathrm{N}$ & $100.29309^{\circ} \mathrm{E}$ & 2989 & Oi & $0-11$ & 0 \\
\hline & & & & $\mathrm{Ah}$ & $11-22$ & 0 \\
\hline & & & & Bw1 & $22-36$ & 0 \\
\hline & & & & Bw2 & $36-60$ & 2 \\
\hline & & & & $\mathrm{C}$ & $60-81$ & 2 \\
\hline & & & & $2 \mathrm{C}$ & $81-100$ & 50 \\
\hline \multirow{5}{*}{$\mathrm{TS} 01$} & $38.27044^{\circ} \mathrm{N}$ & $99.88842^{\circ} \mathrm{E}$ & 2973 & $\mathrm{Ah}$ & $0-16$ & 2 \\
\hline & & & & Bk1 & $16-38$ & 0 \\
\hline & & & & $\mathrm{Bk} 2$ & $38-58$ & 0 \\
\hline & & & & $\mathrm{Bk} 3$ & $58-82$ & 0 \\
\hline & & & & $\mathrm{C}$ & $82-120$ & 0 \\
\hline \multirow[t]{6}{*}{ TS02 } & $38.22806^{\circ} \mathrm{N}$ & $100.04694^{\circ} \mathrm{E}$ & 2833 & $\mathrm{Ah}$ & $0-15$ & 5 \\
\hline & & & & $\mathrm{AB}$ & $15-30$ & 5 \\
\hline & & & & Bk1 & $30-52$ & 10 \\
\hline & & & & $\mathrm{Bk} 2$ & $52-70$ & 10 \\
\hline & & & & $\mathrm{Bk} 3$ & $70-100$ & 10 \\
\hline & & & & $\mathrm{C}$ & $100-120$ & 10 \\
\hline \multirow[t]{6}{*}{$\mathrm{TS} 03$} & $38.80214^{\circ} \mathrm{N}$ & $99.94350^{\circ} \mathrm{E}$ & 2739 & $\mathrm{Ah}$ & $0-15$ & 2 \\
\hline & & & & $\mathrm{AB}$ & $15-25$ & 2 \\
\hline & & & & Bw1 & $25-46$ & 2 \\
\hline & & & & Bw2 & $46-70$ & 2 \\
\hline & & & & $\mathrm{Bk}$ & $70-95$ & 2 \\
\hline & & & & $\mathrm{C}$ & $95-120$ & 2 \\
\hline \multirow[t]{5}{*}{ DS01 } & $39.14629^{\circ} \mathrm{N}$ & $99.35249^{\circ} \mathrm{E}$ & 2177 & A & $0-20$ & 1 \\
\hline & & & & Bk1 & $20-36$ & 1 \\
\hline & & & & $\mathrm{Bk} 2$ & $36-60$ & 1 \\
\hline & & & & $\mathrm{Bk} 3$ & $60-105$ & 1 \\
\hline & & & & $\mathrm{C}$ & $105-120$ & 1 \\
\hline \multirow[t]{5}{*}{ DS02 } & $39.26926^{\circ} \mathrm{N}$ & $99.06039^{\circ} \mathrm{E}$ & 2060 & A & $0-10$ & 3 \\
\hline & & & & $\mathrm{Bk} 1$ & $10-48$ & 12 \\
\hline & & & & $\mathrm{Bk} 2$ & $48-70$ & 2 \\
\hline & & & & $\mathrm{Bk} 3$ & $70-105$ & 1 \\
\hline & & & & $\mathrm{C}$ & $105-120$ & 1 \\
\hline \multirow[t]{4}{*}{ DS03 } & $39.19134^{\circ} \mathrm{N}$ & $99.48514^{\circ} \mathrm{E}$ & 1879 & A & $0-17$ & 0 \\
\hline & & & & $\mathrm{Bk} 1$ & $17-47$ & 0 \\
\hline & & & & $\mathrm{Bk} 2$ & $47-98$ & 0 \\
\hline & & & & $\mathrm{C}$ & $98-120$ & 0 \\
\hline \multirow[t]{5}{*}{$\mathrm{HCO} 01$} & $38.86683^{\circ} \mathrm{N}$ & $100.33540^{\circ} \mathrm{E}$ & 1586 & Ap1 & $0-14$ & 1 \\
\hline & & & & Ap2 & $14-25$ & 1 \\
\hline & & & & $\mathrm{Bu} 1$ & $25-50$ & 1 \\
\hline & & & & Bu2 & $50-80$ & 1 \\
\hline & & & & $\mathrm{Cu}$ & $80-110$ & 1 \\
\hline \multirow[t]{5}{*}{$\mathrm{HCO} 02$} & $38.88606^{\circ} \mathrm{N}$ & $100.37622^{\circ} \mathrm{E}$ & 1547 & $\mathrm{Ap}$ & $0-16$ & 1 \\
\hline & & & & $\mathrm{Bu} 1$ & $16-28$ & 1 \\
\hline & & & & Bu2 & $28-50$ & 1 \\
\hline & & & & $\mathrm{Bu} 3$ & $50-80$ & 5 \\
\hline & & & & $\mathrm{Cu}$ & $80-105$ & 5 \\
\hline \multirow[t]{4}{*}{$\mathrm{HCO} 03$} & $39.49007^{\circ} \mathrm{N}$ & $99.65261^{\circ} \mathrm{E}$ & 1331 & Ap & $0-17$ & 2 \\
\hline & & & & $\mathrm{Bu} 1$ & $17-30$ & 2 \\
\hline & & & & $\mathrm{Bu} 2$ & $30-54$ & 2 \\
\hline & & & & $\mathrm{Bu} 3$ & $54-78$ & 2 \\
\hline
\end{tabular}




\begin{tabular}{|c|c|c|c|c|c|c|}
\hline Site & Latitude & Longitude & Altitude (m) & Horizon & Depth $(\mathrm{cm})$ & Gravel (\%) \\
\hline \multirow[t]{2}{*}{$\mathrm{HCO} 03$} & $39.49007^{\circ} \mathrm{N}$ & $99.65261^{\circ} \mathrm{E}$ & 1331 & $\mathrm{Bku}$ & $78-90$ & 2 \\
\hline & & & & $\mathrm{Cu}$ & $90-120$ & 2 \\
\hline \multirow[t]{6}{*}{ RDD01 } & $40.16214^{\circ} \mathrm{N}$ & $99.41900^{\circ} \mathrm{E}$ & 1205 & A & $0-5$ & 40 \\
\hline & & & & $\mathrm{C} 1$ & $5-26$ & 15 \\
\hline & & & & $\mathrm{C} 2$ & $26-60$ & 5 \\
\hline & & & & $\mathrm{C} 3$ & $60-80$ & 2 \\
\hline & & & & $\mathrm{C} 4$ & $80-100$ & 5 \\
\hline & & & & $\mathrm{C} 5$ & $100-120$ & 2 \\
\hline \multirow[t]{4}{*}{ RDD02 } & $41.03163^{\circ} \mathrm{N}$ & $100.42255^{\circ} \mathrm{E}$ & 1058 & A & $0-8$ & 10 \\
\hline & & & & $2 \mathrm{C} 1$ & $8-20$ & 30 \\
\hline & & & & $2 \mathrm{C} 2$ & $20-58$ & 30 \\
\hline & & & & $2 \mathrm{C} 3$ & $58-100$ & 5 \\
\hline \multirow[t]{4}{*}{ RDD03 } & $40.77397^{\circ} \mathrm{N}$ & $100.13444^{\circ} \mathrm{E}$ & 1111 & A & $0-8$ & 10 \\
\hline & & & & $\mathrm{C}$ & $8-38$ & 15 \\
\hline & & & & $2 \mathrm{C} 1$ & $38-73$ & 15 \\
\hline & & & & $2 \mathrm{C} 2$ & $73-103$ & 2 \\
\hline \multirow[t]{5}{*}{ AGD01 } & $41.87041^{\circ} \mathrm{N}$ & $100.58152^{\circ} \mathrm{E}$ & 965 & A & $0-6$ & 1 \\
\hline & & & & Bw1 & $6-30$ & 15 \\
\hline & & & & Bw2 & $30-57$ & 50 \\
\hline & & & & $2 \mathrm{C} 1$ & $57-86$ & 90 \\
\hline & & & & $2 \mathrm{C} 2$ & $86-120$ & 90 \\
\hline \multirow[t]{4}{*}{ AGD02 } & $41.69688^{\circ} \mathrm{N}$ & $100.28950^{\circ} \mathrm{E}$ & 992 & Ay & $0-10$ & 10 \\
\hline & & & & $\mathrm{BC}$ & $10-52$ & 30 \\
\hline & & & & $2 \mathrm{C} 1$ & $52-82$ & 30 \\
\hline & & & & $2 \mathrm{C} 2$ & $82-100$ & 30 \\
\hline \multirow[t]{4}{*}{ AGD03 } & $41.23336^{\circ} \mathrm{N}$ & $100.50868^{\circ} \mathrm{E}$ & 1033 & A & $0-10$ & 3 \\
\hline & & & & $\mathrm{Bw}$ & $10-45$ & 10 \\
\hline & & & & $2 \mathrm{C} 1$ & $45-86$ & 75 \\
\hline & & & & $2 \mathrm{C} 2$ & $86-120$ & 75 \\
\hline \multirow[t]{3}{*}{ SD01 } & $39.35686^{\circ} \mathrm{N}$ & $99.14116^{\circ} \mathrm{E}$ & 1600 & $\mathrm{C} 1$ & $0-9$ & 0 \\
\hline & & & & $\mathrm{C} 2$ & $9-85$ & 0 \\
\hline & & & & $\mathrm{C} 3$ & $85-120$ & 0 \\
\hline \multirow[t]{3}{*}{ SD02 } & $39.62055^{\circ} \mathrm{N}$ & $99.60005^{\circ} \mathrm{E}$ & 1312 & $\mathrm{C} 1$ & $0-10$ & 2 \\
\hline & & & & $\mathrm{C} 2$ & $10-40$ & 2 \\
\hline & & & & $\mathrm{C} 3$ & $40-100$ & 2 \\
\hline \multirow[t]{3}{*}{$\mathrm{SD} 03$} & $40.66165^{\circ} \mathrm{N}$ & $101.42041^{\circ} \mathrm{E}$ & 1068 & $\mathrm{C} 1$ & $0-15$ & 2 \\
\hline & & & & $\mathrm{C} 2$ & $15-65$ & 2 \\
\hline & & & & $\mathrm{C} 3$ & $65-120$ & 2 \\
\hline
\end{tabular}

Note: AM, alpine meadow; SSM, subalpine shrub and meadow; MG, mountain grassland; MF, mountain forest; TS, typical steppe; DS, desert steppe; HCO, Hexi Corridor oases cropland; RDD, Ruoshui River delta desert; AGD, Alxa Gobi desert; SD, sandy desert. Horizon designation follows the methods of Schoeneberger et al. (2012). Horizon: O, organic horizon; A, surface horizon; B, subsoil; C, substratum; $\mathrm{AB}$ and $\mathrm{BC}$, transitional horizon. Horizon suffix: b, buried genetic horizon; $\mathrm{h}$, organic matter accumulation; i, slightly decomposed organic matter; jj, evidence of cryoturbation; $\mathrm{k}$, pedogenic $\mathrm{CaCO}_{3}$ accumulation; $\mathrm{p}$, plow layer; u, presence of human-manufactured materials; w, weak color or structure within B (used only with B); y, accumulation of gypsum. Numerical prefix (i.e., 2) is used to denote lithologic discontinuity (e.g., 2C, 3C). Numerical suffixes (i.e., 1, 2, 3) are used to denote subdivisions within a master horizon (e.g., Bk1, Bk2). 